\title{
A Fishy Romance: Chiefly Power and the \\ Geopolitics of Desire
}

\section{Heather E Young Leslie}

Tau ina uia le ala o le atu (Let it go the way of the bonito).
SAMOAN PROVERB

Ongomai, ongomai 'a Nganatatafu mei Tonga: 'oku te'eki ai kema sio he tamasi'i talavou mo'oni! (I have heard tell, word has come, of Nganatatafu from Tonga: never before have we seen such a truly beautiful boy!)

HINA OF ALEIPATA'S SINIFU (MAIDEN ATTENDANT), AS TOLD BY HIKO OF TONGA, 2003

A beautiful man is beautiful to see, but a good man will always beautiful be.

SAPPHO (ANCIENT GREEK LYRIC POET)

The story of the Tà'atu, a fish harvesting technique traditionally conducted in the Tongan village of $\mathrm{Ha}^{\text {'ano, }}$, is the closest thing the village has to a founding myth and mystical justification for the traditional estate of its hereditary chief. In this paper, I consider the tale of the Tà' atu as told by Saia Fifita, the man who for several decades has held the ceremonial name of Hiko (see photo I). The Hiko name is linked as a tehina or "junior brother" to the title of Ha'ano's traditional chief, the Tu'iha'angana. ${ }^{1}$ When connected to local place-names, proverbs, poetry, genealogies, and cross-Polynesian narratives, the story of the Ta' 'atu provides fragmentary (yet rich) insights into the significance of desire in past political geographies and ecologies. Desire features as the rationale for a phenomenology of place-landscapes, seascapes, and those who populate the "memoryscapes"-that connects the traditions of the past to the political and 
environmental exigencies of the present. The events recorded in the Ta' 'atu predate and yet still frame contemporary Tongan political and social experience. Thus, the Ta'atu offers a meaningful standpoint for the juxtapositions of contemporary and past chiefly-commoner relations. But because the Ta'a atu records events related to a ritualized method for harvesting skipjack tuna, the Tà'atu provides an equally significant standpoint for considering the present-day sustainability of a fishery on which Polynesians have thrived for thousands of years.

Not quite a history, nor simply a ritual harvesting technique and accompanying tale, the Tā'atu is what I am calling an "ecography." By ecography I refer to the inscription of human history and agency in a place and its inhabitants, and a mutual reinscription of land, sea, and dwellers into human lives, by way of place-names, emplaced stories, ceremonial titles, and remembered ritual. In this particular ecography-or at least in my own rereading of it-elements of pan-Polynesian concerns with procreation and generativity, with beauty and the sacred act of sex as precedent to "bounty," figure as motivators for ocean voyaging, as rationales for generations of privilege and power, but also as benchmarks for contemporary shifts in a human-fish relationship that has provided centuries of pragmatic and poetic sustenance for Polynesians. Imbricated in these shifts are tensions in chiefly-commoner relations in the last nation to claim status as an uninterrupted Polynesian polity. Yet in today's world of multinational commercial fishing fleets, global warming, and widespread contamination of marine ecosystems, where fish like the 'atu are evaluated on the basis of their percentage of the overall contribution to national economies and transnational shareholders' profits, where floating factories harvest in waters far from home affecting local inshore fisheries in unprecedented ways, that same geopolitics of desire is transfigured, and in that transfiguring, fish and human ecographies are changed.

As Marie-Claire Bataille-Benguigui documented (I988), in Tonga, ocean denizens such as fish, sharks, and turtles should be understood as "partners" rather than prey. Similar arguments- that the animals on which people depend for sustenance willingly cooperate in that process-have been made by other foraging and hunting peoples, such as the Cree of Quebec (Feit I995, I99I), the Dene of Northern British Columbia (Brody I98I), or the many nations of the northwest coast of Canada and the United States (see, eg, Gunther 1928; Jenness 1955, 6-9). All describe moose, beaver, salmon, and other animals as sentient beings who give themselves as food to humans, often out of love. Even predators and humans have 
found that cooperation and respect is mutually beneficial, as Elizabeth Marshall Thomas's work on lions and Ju/'hoansi in the Kalahari demonstrates (2003), and as any Polynesians who count the shark as part of their ancestral genealogy may attest.

In Ha'ano, those partners are the fish called 'atu, and the ritual method for harvesting the 'atu-called a Ta'a $a$ atu-is encoded in story and placenames. As well as prescribing how to harvest the 'atu, the narrative of the Ta'atu simultaneously justifies the position of the traditional chief, the Tu'iha'angana, as chief of that island, and marks the island's place in Tongan history and the geographic politics of the central Pacific. Yet the Ta' 'atu harvest itself is becoming a dim memory, as the bounty of 'atu on which the original Ta' 'atu story is based becomes less dependable and less abundant, as fish have been reclassified from "partners" to "trade stocks," and as the tenor of the relationship between traditional chiefs and nonchiefly residents changes. When knowledge of this ritual fishing method and how to conduct it passes, so too will go an integral aspect of the mystical connection between the Tu'iha'angana and the island and people that constitute his hereditary tofi'a (estate). Polynesian chiefliness-which in Tonga is a dyadic relation of 'ofa (generosity/love) balanced by talangofua and faka'apa'apa (obedience and respect/reverence)—works through affective ties: the hou'eiki (chiefs/chiefly people) are considered "good" chiefs and are obeyed and revered when the "ofa they have for their people is manifest in generous bounties, which they empower through their very being. In the "old days," a chief was such, partly because his or her mana was powerful: it was fertile, beneficial, and productive (in the Foucauldian sense of "pouvoir") to those within the chief's arc of influence and

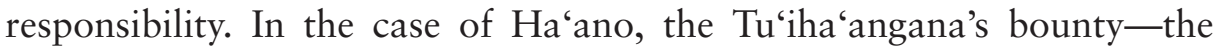
annual and plentiful runs of 'atu-is described as the direct result of his beauty and desirability. For the kau Ha'ano (people of Ha'ano), who are described traditionally as part of his kāinga (extended kin/people of his estate), the 'atu is a gift of love, sent from Sāmoa. But this love gift has failed to appear for many years. The contemporary absence of the fish resituates the Tà'atu into another, different ecography-one tangled with desires for profit margins, fish stock preservation, and national boundary making in a globalized world economy. But even this version of the ecography continues to revolve around themes of bounty, power, ocean voyaging, beauty, and desire. Today, as in the past, the Ta' 'atu is a fishy tale about the geopolitics of desire. I begin my telling of this fishy romance with its star attraction, the fish called 'atu. 


\section{Long-term Partners: Pelagic Fish and Polynesian Fishing}

The 'atu, as it is called in Tonga (atu in Sāmoa and aku in Hawai'i), is sometimes called "bonito" and sometimes "skipjack" in the fisheries literature. The apparent confusion of terms results in part from language and local historical uses. In general, the broad lay use of the term "bonito" refers to a variety of mostly Pacific Ocean-based fishes of the genus Sarda of the family Scombridae. They are a type of tuna; the scientific designation is Katsuwonus pelamis. While "skipjack" is the most specific label and "bonito" a more general term, the latter label is more commonly used in the nonscientific, older, and nonspecialist literature. As such, it coincidentally reflects the general Polynesian classification, insofar as the terms 'atu, atu, and aku (Tongan, Samoan, and Hawaiian, respectively) do not distinguish between varieties of bonito. 'Atu (skipjack) are relatively small for tuna, rarely exceeding twenty-five pounds. They tend to be silver bellied, with steel blue colored backs and dark blue stripes running along the upper half of the body. The meat has less fat content than salmonid fish and a stronger, slightly oilier flavor than other members of the tuna family.

Like other tuna, bonito (including skipjack) are a highly migratory, hunting, pelagic (open ocean) species. In this respect, bonito are similar to whales, sharks, porpoises-and, I would add, Polynesians. A map of bonito spawning and sea-range areas reaches from coastal Philippines and China to the coast of South America, between the tropics of Cancer and Capricorn. Their ranges rather neatly coincide with a map of Lapita, ProtoPolynesian, and Polynesian territories. The wide range of the 'atu territory must have contributed to their attractiveness to those very pre-nineteenth century voyagers whose knowledge of the sea was built on cognitive maps created while fishing, and whose exploration and discovery of the Pacific islands depended as much on an ability to exploit shifts in weather patterns (see, eg, Irwin I992; Finney 1993), as on their knowledge of specific oceanic food sources. 'Atu (skipjack, and bonito in general) do follow regular seasonal patterns that are recognized by people across the Pacific. Where the fish are to be found at any one time, however, depends specifically on temperature gradients and ocean weather patterns. As contemporary commercial fishers know, an El Niño or La Niña oscillation, which affects the temperature and direction of the Pacific currents (as well as cycles of rain, drought, or other weather patterns), affects where the fish will spawn and later congregate. A dependable, regular run of fish that beached themselves on a particular island would be an important resource. At the same 
time, as James Acheson indicated (I98I), even annual runs of fish such as salmon or bonito offer small windows of opportunity for maximizing a catch: miss the run and it is gone for a year. Thus, the normal variations of timing in the fishes' return - even if slight-must have contributed to the development of ritual and story aimed at ensuring the dependability of the resource.

While certainly not the only source of food available in ancestral times, pelagic fish were clearly important, as was the barbless hook used to catch them. ${ }^{2}$ Both are linked to narratives of Pacific voyaging. Probably the most famous story is the explanation for how Anuta, most of Tonga, Sāmoa, and Te Ika a Maui (the North Island of Aotearoa/New Zealand) were created: Maui, so the various stories say, was out fishing. With his marvelous hook, he pulled up sections of the sea floor itself, creating islands. Likewise, a mighty bonito hook was used to move the island of Moku'ola, and to try to draw Hawai'i closer to Tahiti.

In another equally compelling if slightly less fantastic metaphor, the prophet Makuaka'umana, who sailed from Bora Bora to Hawai'i with the priest Pa'ao, was recorded as having said: "A fragile-tailed fish am I,/Moving swiftly before the heavens, /Traveling the dark, dark ocean" (Kamakau I993). Similarly, Teuira Henry recounted an old chant from $\mathrm{Ra}$ 'iatea that tells of Hina and her brother Ru who discovered several islands while out fishing (I928). The chant ends with Hina's desire for exploration being so strong that she set sail for the moon (where she now resides). Both Makuaka'umana's metaphor as he began his epic voyage and the chant of Hina of Ra'iatea clearly demonstrate the symbolic associations between fish and voyaging. Maui's land-fishing technique has been described as a poetic device for open ocean navigation and island discovery (Kawaharada [2000]). While I would not gainsay that interpretation, the existence of so many fish tales from across the Polynesian world seems to me an equally compelling description of the practical as well as poetic importance of fish and fishing in ancestral Pacific cultures.

That 'atu and humans have a long and geographically distributed coexistence is also attested to by special canoe styles specific to bonito hunting, such as were found on Kapingamarangi (Emory I965, 216), and fishhook styles appropriate for bonito (including skipjack) found in archaeological sites across the Pacific (Kirch and Green 200I, I3 I-I4O; Kirch 2000, III). Of those sites, Tonga is presently recognized as the place with the earliest dates for Lapita people in Remote Oceania (Burley and Dickinson 200I). Archaeological reconstruction of the early Lapita settlement pat- 
tern across the Pacific indicates a homogeneous preference for atolls rather than high islands, and "a coastal, back-beach setting facing a leeward lagoon or reef with easy access to navigable water" (Burley I998, 354). This description fits the setting of the village of $\mathrm{Ha}$ 'ano perfectly. Archaeological dating places the original settlement on the island to some 2,900 years BP (Dickinson and others 1994, I03). As in other parts of Polynesia, the original inhabitants of Tonga (including Ha'ano) were excellent exploiters of their sea environment, even while they transformed the atolls into productive gardens. ${ }^{3}$ The degree to which land food was responsible for the enduring population is not as well documented archaeologically in the low atolls of the Ha'apai area as some other parts of the Pacific. Chris Gosden argued that prehistoric subsistence systems in the Pacific east of the Solomons, after $3000 \mathrm{BP}$, indicate considerable diversity, including tree and root cropping (1992). It seems clear that the early discoverers of the central Pacific islands such as Tonga brought with them a systematic set of ideas about cultivation, a "transported landscape" that included a propensity for swamp and roots-based cultivation (Will McClatchey, pers comm, 2003). There is no doubt that by I777, when Captain James Cook arrived in Tonga-just in time to observe an 'inasi or first fruits ceremony in honor of then Tu'i Tonga Paulahi-farming was well established: ceremonies emphasized the significance of the growing season (Perminow 200I; Stevens 2002). But land food may not always have been enough, especially on the outer atolls like $\mathrm{Ha}$ 'ano, which is small and low-roughly I by 4 kilometers, no more than 20 meters above sea level-and subject to the vagaries of weather including drought and storms with sea surges. Yet the island of $\mathrm{Ha}$ 'ano, which has been continuously occupied for some 2,900 years, at one time supported enough of a population to provide for a resident chiefly elite, monumental architecture, and what became four separate villages (map I). ${ }^{4}$

The archaeological and mythic evidence for the significance of fish and ocean harvesting is likewise supported by the various chiefly titles and names that reference fishing in Tonga (Bataille-Benguigui 1988; Gifford I 929, I 48-I 52, 237-276, especially $239,243,249-25$ I). This seems to be true for Sāmoa too, as demonstrated by the numerous fish-oriented proverbs collated by Craig Severance and Robert Franco (I989, 6-I 5). Evidence from other parts of Oceania also supports the point that early discoverers of Pacific islands and atolls depended heavily on fishing and marine resources (Leach and others I984; Kirch and Ellison I994; Butler I994, 200I). The heavy bonito runs on which the Ta' 'atu is based were, I 


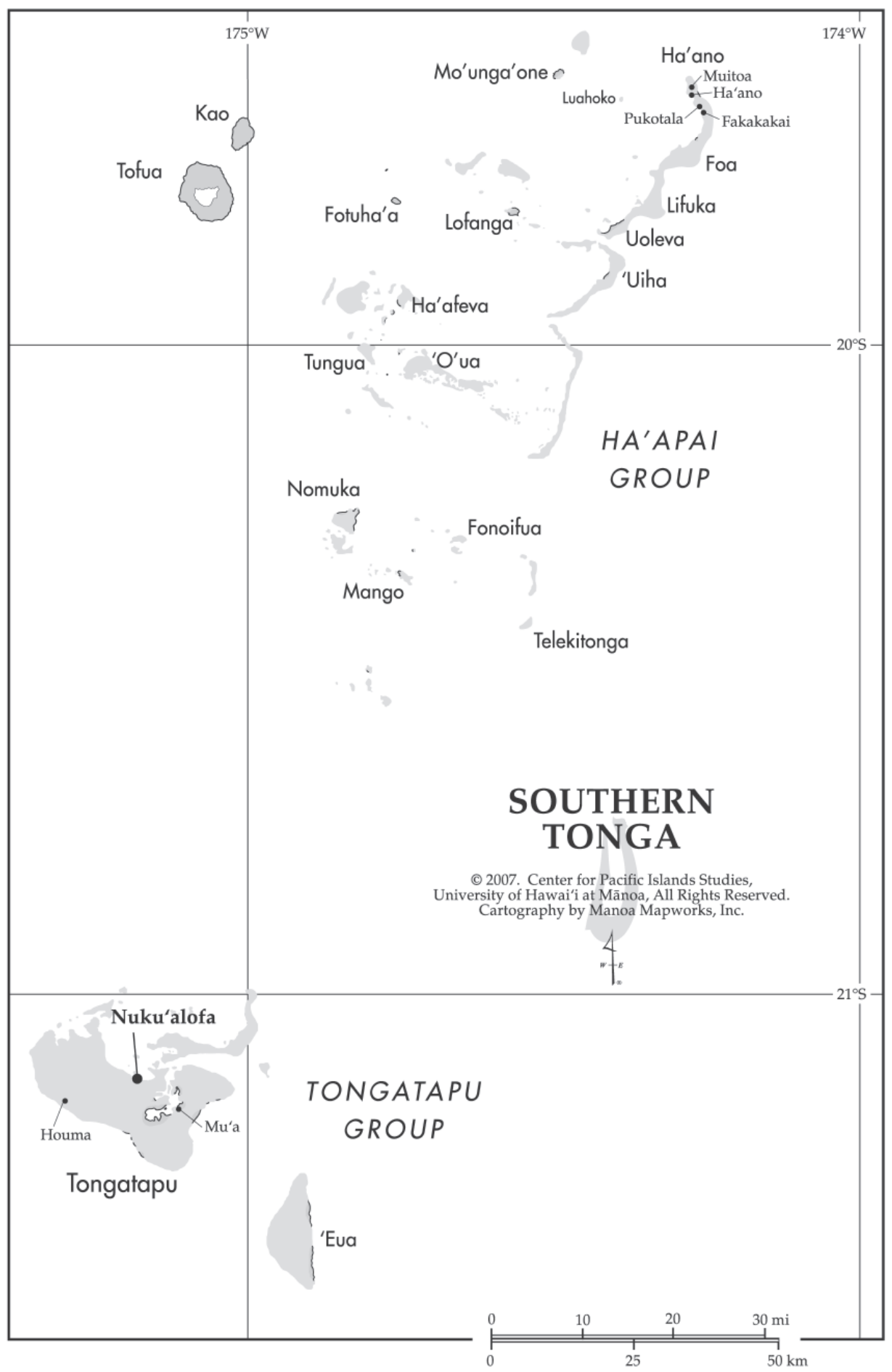

MAP I. 
suspect, essential to both the prolonged habitation of Ha'ano island and $\mathrm{Ha}$ 'ano village's rise as a chiefly seat of power through the Tongan classical period of the twelfth century into the early nineteenth century. The Tu'iha'angana's estate is tiny relative to others in Tonga, and the family is at present not quite as prestigious or powerful as it may have been in the past. It is, however, acknowledged to be one of the most ancient titles in Tonga's history (Bott with Tavi I982, 95), an importance that I suspect depended heavily on the past bounty of the 'atu.

Fishing is still an important part of the Ha'ano economy, where men typically farm, raise pigs, and fish (see Evans 200I). Contemporary fishers use outboard motors, longlines, surround nets, throw nets, fish corrals, spearguns, and night torches to exploit both the reef and the deeper ocean beyond. While the Ta' 'atu ritual is rare now, long years after the establishment of the village and the emergence of the Tu'iha'angana line of chiefs, $\mathrm{Ha}$ 'ano's elder fishers still tell of 'atu coming through the reef into the small, sandy bay in such numbers that they actually leapt onto the beach. These are not just fish tales: Hiko described four Tā'atu which he himself participated in (or presided over), and at least two other specialist fishers in the village, Vili Maea and Lautala Taufa, told me about their experiences with major runs in which the 'atu came through the reef into the small bay and threw themselves onto the land (see also Bataille-Benguigui 1988). Bonito (including skipjack) are known to beach themselves in other parts of the Pacific such as Kapingamarangi (Emory 1965; Michael D Lieber, pers comm, 2002; see also Lieber I994); Tahiti (Barbara Walker, pers comm, 2004); and Tuvalu (Keith Chambers, pers comm, 2002). The harvesting techniques elsewhere are similar to those described in the Tá' $a$ atu, but the Tà'atu story itself seems specific to Ha'ano. In fact, in Houma, on the island of Tongatapu in Tonga (see map I), the bonito are also known to run into the shore in large numbers, even to beach themselves (Maile Drake, pers comm, 2004). Yet it is Ha'ano alone that frames the event in

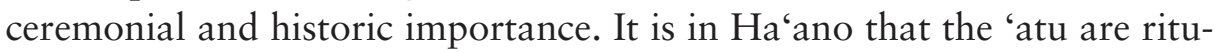
ally honored, and the Tà'atu (ritual and story) becomes ecography.

\section{The TĀ'ATU}

According to Hiko (photo I), when people see the signs that the 'atu are coming-birds out at sea diving and swooping, and a ruffled, churning appearance to the water as the fish surge at the surface (from which the "skipjack" gets its name)-they are supposed to inform Hiko. He is 
responsible for gathering people together from the entire island, organizing the harvest, and managing the distribution of the fish. As he has described it to me, the proper way to conduct a Ta'atu is with a large number of people and a surround net (kupenga). The old-fashioned way was to use a long rope $(\mathrm{au})$ with coconut fronds suspended from it to create a kind of underwater curtain. This rope was stretched across the bay, with a gap for the spot in the reef where the bonito were to enter. People swam and held the line, and splashed the water to herd the fish toward the shore, where others waited to toss the fish by hand onto the beach. In later years, burlap copra sacks held open with a flexible branch were used to scoop up the fish (Bataille-Benguigui I988, I90). A key difference between this and bonito harvests elsewhere, as well as other types of fishing in Ha'ano, is that during a Tà'atu, it is absolutely forbidden to strike the fish, to cause them to bleed, or to sell any part of the catch. ${ }^{5}$

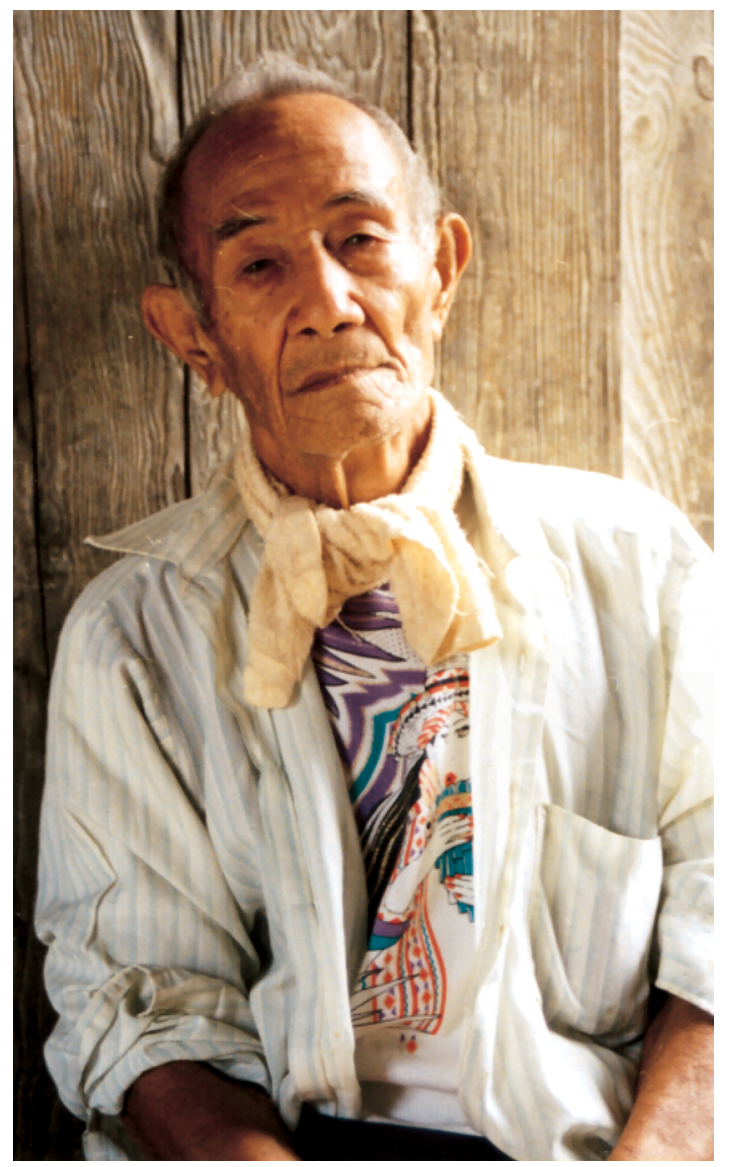

Рното г. Hiko, just after telling the Ta'a'atu story in 2003 . Photograph by Heather E Young Leslie. 
According to Hiko and other senior men and women of the village (Pouvalu, Sisi Kakala, Peito, Vili Maea, Folingi Katoa, and Mele 'Ungatea), the first shares of the catch must go to the Tu'iha'angana, as the chief of $\mathrm{Ha}$ 'ano, and then to other highly ranked persons in the kingdom. In previous times this would have included other paramount and chiefly persons such as the Tu'i Tonga, just as with any other first fruits or 'inasi (ceremonial distribution). Today, according to Hiko, fish from a Ta'a'atu would be distributed to the Tu'iha'angana, and also to the king, the prime minister, the governor, heads of all the churches, and other dignitaries such as the motu'a tauhi fonua (elders who nurture/guard the land) who protect $\mathrm{Ha}$ 'ano, and the various mātāpule (chiefly attendants) who represent the Tu'iha'angana in the village. The bulk of the fish would then be distributed among the people of the Ha'angana estate (the villages of $\mathrm{Ha}^{\text {'anon, }}$ Pukotala, and Muitoa). Hiko must oversee the entire event, while the Tu'iha'angana must undergo a ritual seclusion throughout the harvest.

If the fish are struck or caused to bleed, if they are sold, or if the Tu'iha'angana comes out of his house, the Tà'atu lore says that the 'atu will go away and not return, at least not without some sort of special intercession. ${ }^{6}$ Bataille-Benguigui recounted an event from 1975 wherein Hiko, standing waist deep in Ha'ano's harbor and wearing the traditional waist mat of fau (hibiscus fiber), made a public offering of kava and apologized to the fish for any wrongdoing on the part of the villagers (I988). Hiko's purpose at that time was to beg the 'atu to return to Ha'ano; none had come to the village since I970, when a harpoon had supposedly been used during a Tà'atu. The fish did return after that, Hiko and other fishers in the village agree, but the returns were not consistent. By I99I, when

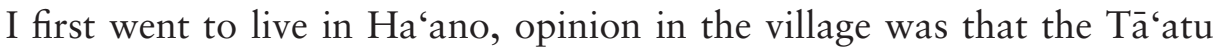
was a wonderful sight to behold, a marvelous thing, especially when the bonito threw themselves on the shore, but that they did not come every year, and they had certainly stayed away for a long time. Few people then had actually seen a Ta'a atu. This was considered by some in the village to be evidence that the Ta' atu was simply a superstition from the old days. Others speculated that the absence of the prodigious numbers of fish was perhaps because a man had built a fish corral and captured a lot of bonito in the mid-I980s. In retrospect, they thought, perhaps the fish should have been harvested and distributed according to the Ta'atu rules. While the man had not struck any of the bonito caught in his fish fence, and had freely distributed much of his catch, some of it had indeed been sold to pay for a bank loan, and the fish had not been caught by hand. This error 
had not been remedied by a second propitiation ceremony, although the fisherman did make a large church donation that year.

In I99I, Hiko, then a spry man in his early eighties, was too elderly and considered too old-fashioned to garner village support for a repeat ceremonial invitation to Hina's fish. By 2003, when we began talking about the Ta'atu story and village history in general, Hiko was barely able to walk, and it was increasingly common for younger villagers to laugh at his old-fashioned speech and mannerisms. In that year people speculated that the bonito no longer come because the "Chinese and other foreigners and fish pirates" (paraphrasing various villagers' statements) have been catching and selling them before they can get to $\mathrm{Ha}^{6}{ }^{6}{ }^{2}{ }^{7}{ }^{7}$

However, Hiko and some of the other elder men say that the fish have not returned because Hiko himself, in a pique of anger, swore at Hina and sent her fish away. According to Hiko (pers comm, 2004), the last time the fish came-sometime in the late r980s-he called for the people to come for the Ta'atu. Hiko went out and paddled three times around the bay, leading the fish in circles, ready to bring them in to shore, but the people did not get ready. So, angry at their lack of respect for the old traditions, Hiko says he sent Hina away, abusing her with profanities (as he tells it, in this instance, Hina and the 'atu are one).

It should be noted that it was about this same time that the reef around the bay began to change: attempts were being made to widen the passage, and small, I 5-30 horsepower fishing boats began to dominate the fishing industry on the island. Likewise, large-scale commercial fishing by international fleets began to increase in central Pacific waters. Loss of reef (and the small food sources on which the 'atu were feeding before they beached themselves), or decimation of the large schools of pelagic fish, or both, likely coincided with the time that Hiko conducted his last ceremony with the 'atu. Whatever the explanation, people agree it is a tragic fate for a gift of love, and a serious loss for the village.

\section{A Gift of Love: Hina and Nganatatafu}

The special technique for harvesting bonito when they swarm into the bay of Ha'ano, the Tu'iha'angana's ritual seclusion, and the reason the fish actually come to $\mathrm{Ha}^{\prime}$ ano at all, are all explained in the story of the Samoan beauty, Hina, and her courageous and beautiful Tongan lover, Nganatatafu. The story, as Hiko has told it to me over the years, and which I recorded in 2004, goes like this (translation and adaptation my own): ${ }^{8}$ 
Ngana 'Eikimeimu'a, a son of the Tu'i Tonga Tatafu'eikimeimu'a, set sail from Tongatapu for Sāmoa, lured by the beauty of Hina. She was a taupou [ceremonial village virgin/chiefly daughter] of Aleipata [in Upolu, Sāmoa], and reports of her beauty had reached Ngana 'Eiki. He intended to woo her. On the way,

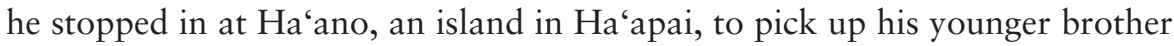
Nganatatafu, the chief of that island. As the voyaging party finally reached the shores at Aleipata in Sāmoa, Ngana 'Eiki showed that he was suspicious of his brother. Young Nganatatafu was exceedingly beautiful and Ngana 'Eiki did not want the competition for Hina's affections. So he charged his brother with guarding the boats while the rest of the party went ashore. Nganatatafu obediently told his elder brother, "As you wish," and stayed behind. When we next hear of him, he had been swimming and was resting on the beach within sight of the boats.

Ngana 'Eiki and the rest of the voyaging party went up to the village and a great festive time ensued, with much merrymaking. Eventually, of course, the visitors got hungry, and Hina sent her sinifu [a maiden attendant], to gather some seawater to make 'ota [raw fish] for the guests. At the shore, the sinifu suddenly spied a young man lying face down, naked, with his clothes nearby, drying in the sun. The girl gazed on him in wonder. She thought to herself, "I have never seen anything so beautiful; who—or what—could it be? Perhaps it is a spirit?" She decided, "I will go over there with my hohoni [coconut shell bottles] and test to see if he is human. I will rattle my hohoni, and if he jumps for his clothes, well then I will know that he is human."

But just then a second girl came along, sent by Hina to find out why the first had been delayed so long. The young man was still lying there, face down, naked and resplendent. Together the girls decided to test whether he was human or not by rattling their hohoni and making noise. They agreed, "If he is a spirit, he will disappear, but if he is human, he will jump for his clothes." They banged their hohoni, and indeed Nganatatafu did startle, jump up, and reach toward his clothes. The girls were much relieved to ascertain that he was a live youth.

When they got back, Hina was very angry that the first girl had taken so long, because the guests were hungry. She declared her sinifu's punishment was to be death ["It was dark times, eh?" says Hiko as an aside at this point]. The sinifu said to Hina, "Please wait, I beg you, listen to what we have to say first! I have heard tell, word has come, of Nganatatafu from Tonga. Never before have we seen such a truly beautiful boy. He is the reason I was delayed in my task." The sinifu described to Hina what they had seen. Hina asked, "And where is he?" "He is at the shore, lying down, naked, while his clothes dry on the sand," they replied. "He did not see us, and we thought to bang together the hohoni to see if he would wake and jump up and grab his clothes, 
or, if he was a spirit, disappear. We clashed our hohoni, and he jumped for his clothes."

Convinced that it was indeed Nganatatafu there at the shore, Hina thought, "Well, this is an opportunity; Nganatatafu, here." She said, "Fine, you are forgiven. The chief must be parched after his long sea voyage." Hina told them, "Bring my bottle of scented oil, and go and give it to Nganatatafu. Tell him to keep it there." Hina then returned to the po'ula [evening festivities]. But Nganatatafu did not stay at the beach. He came up from sea and stood in the onshore breeze. He had Hina's bottle of scented oil with him, and he played with it, opening and sniffing it-so that he would know her scent and be able to use it find her in the dark-as she intended. Soon the chiefs went to rest. Immediately, up came the youth, himself scented with Hina's oil. As the Tongan visitors retired to sleep, Nganatatafu came to Hina and they talked, just the two of them, long into the night.

When they were finished talking, Hina went and brought her ngafingafi [Tongan term for a very special pandanus textile, called 'ie sina in Sāmoa, used for very special occasions, including chiefly deflowerings] and they slept [mohe; ie, had sexual intercourse] together. ${ }^{9}$ Afterward, Hina said, "Ngana, I have no love gift that I can give you. If you go with my koloa [wealth object], it will be lost, or could be sold for money; you shall go with my fish. If you went with my ngafingafi, it would eventually rot, but if you go with my fish, it will always be with you."

Then Hina gave Nganatatafu the instructions for the ritual of the Ta'atu. She told him: "Do not hit my fish, or sell it, or it will never come again" [spoken in the chiefly register]. "See that you do not forget-know that this is a remembrance of me. Also, don't you go to the sea when my fish come, because if you go to the sea, I will be embarrassed by the rite [to'onga] we have just performed. Instead, find your younger brother [tehina]; give him the task to go and harvest the fish, my fish, and distribute them."

But that, says Hiko, is not the end of the story!

The voyage back from Sāmoa was an unpleasant trip. Ngana 'Eikimeimu'a was angry about what Nganatatafu and Hina had done. While on board the boat as they came near to the island of Mo'unga'one [see map I], the men began to prepare kava. Ngana "Eiki abruptly stood up and told Nganatatafu and his unfortunate Fijian attendant, "You two! Dive in! Go to Ha'ano!" ["Yes, see?" says Hiko. "He did it to kill them. See? To swim from Mo'unga'one to here? How many miles is that?" At this point in the story, Hiko points in the direction of distant, barely visible Mo'unga'one, laughs and shakes his head.] But before they went, Nganatatafu spoke eloquently: "Give me some kava first; 
bring my kava and then I will jump in." Although the kava was not ready [it was still coarse], they drank, and then-splash!-they jumped in together: he, the Fijian attendant, and Hina's fish. They swam, especially the little fish from Sāmoa! They fairly sailed along, so swiftly swam the fish. While the boat sailed away, the fish followed Nganatatafu like a rudder, like the wave from a

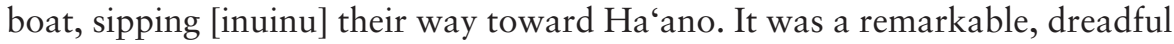
thing, to have to swim the open ocean, while the other chiefs sailed on to Tongatapu, careless of their cruel deed. But Nganatatafu and his Fijian man swam and swam, and little bit by little bit, flailing along, finally they got very close, almost to Ha'ano. Just before the shore, at the inner reef, Nganatatafu climbed up, and saw his Fijian, still swimming, almost there. But as the attendant came nearer, as he was almost to the point on the reef where Nganatatafu stood, just as Nganatatafu put out his hand to pull him in, the Fijian man died. It was very sad. That part of the reef is still there and has been named Ma'ukuomate, which means "made it, but already dead."

But this too is not the end of the story! When he tells the story, Hiko includes the signs for knowing when the 'atu are coming: The birds are agitated, diving down to the sea. The water darkens and ruffles as the fish "skip" near the surface. When Hiko determines that Hina's fish are indeed coming, he raises the alarm, while the Tu'iha'angana goes, with two of his mātāpule, to stay in the house. When he tells this part of the story, Hiko begins to gesture, reliving the past experiences: He recalls sending a horse to Pukotala and Fakakakai (villages to the south), to tell the people "Fish!" He says, "Tell it to Muitoa [village to the north]: Fish!" He calls for people to bang their tin roofs, toll the lali (log drum), and call out "Everyone, everyone, come here, to the sea!"

When they gather, the people together plait a big rope (au) of coconut sennit and fronds, long enough to encircle inside the reef, and act like a big corral for the 'atu. People join together to make the rope, and then some swim out, some paddle in canoes, and some wade in the shallows to hold the rope, herd the fish toward shore, or scoop them up. Hiko, wearing a special kiefau (waist mat made of hibiscus bark and pandanus, traditional for fishing chiefs) stays in the center, sitting in the popao (canoe), and the fish come toward him. ${ }^{10}$ As they come in, the people gather up the fish, carefully, without hurting them. Some of the fish jump right up to the shore, to the dry sand. Those fish are set aside specifically for the Tu'iha'angana. The rest of the fish are distributed to the hou'eiki (chiefly elites) of the kingdom, and to the islanders, as already described. In a proper Tà'atu, Hiko reiterates, the fish are not sold. 
The story is finished when Hiko says, "This little house is important in terms of fish, that's the truth. The road of the fish ends here but begins in the deep sea; they leave the sea, and this is their tomb."

As entertaining narratives go, Hiko's 2003 and 2004 tellings are not the most eloquent versions available. The earliest known printed version of the story of the lovers Hina and Nganatatafu appears in the inaugural issue of the Tongan Wesleyan newsletter Ko e Fanogonogo (Baker I9I6); ethnographer Edward Winslow Gifford reprinted it in his collation of myths and tales (I924, 55-58). That version is more detailed than Hiko's most recent telling. In particular, it includes a description of Nganatatafu's beautiful hair. It was the color of ripe (red) pandanus fruit at the temples, and women described as "like fire"-hence, perhaps, the name "tatafu" (tafu references fire). It was so lovely that women fainted at the sight of it. This perhaps, is the reason that the sinifu in Sāmoa knew it was Nganatatafu when they startled him: in addition to revealing his nakedness when he jumped up, he probably also revealed his signature hair.

Among other things, Hiko's most recent version reflects the fact that he knows he has told me the story on previous occasions. Hiko was also quite elderly-he estimates ninety years old-in 2004. Some aspects of the story are clearly abridged, even in my memory of what he has told me in the past. But each of Hiko's versions carried the same essential elements that also appear in the other published versions (see, eg, Gifford I $924,55-58$ ), with some added emphases that relate specifically to his own role in the process: Hiko is very clear, and emphatic when he says "it is I who directs. Havea (the Tu'iha'angana) must stay here. It is essential that Havea does not join in this thing. If Havea appeared, we would not have a Tà (as in Tàa atu) here; the fish would go. Hina is very shy about what they did-that is the reason Havea is banned from the beach, from the sea: Hina said to Nganatatafu: find your younger brother so that he may manage the entire thing."

\section{TĀ'atu as Ecography: Mythic Structures and Mnemonic Terrains}

As told since at least I9I6, this is a story that outlines the behavioral and moral expectations of key social categories of persons in the Polynesian social world: junior brothers, chiefly retainers and virgin daughters are to be obedient and loyal; elder siblings, sacred virgins, and paramount chiefs wield unquestioned authority, even the prerogative of death. The 
story embeds the sources of chiefliness in the sacred, supernatural realm, and indexes mana in physical beauty and feats of audacity, courage, and strength. But it is also an ecography which fixes the village of $\mathrm{Ha}$ 'ano into a wider social and geopolitical sphere, one that includes human and sea partners, and situates the line of the Tu'iha'angana as the source of the magical love gift - the annual runs of bonito - from which the villages on the island have often benefited. At a more prosaic level, the story explains the Tu'iha'angana's privilege and justifies his ongoing position vis-à-vis other holders of Tongan chiefly titles. Likewise, it authorizes Hiko's own position as a tehina and as one of the ceremonial leaders of the village. The story is clearly a mythic charter in the Malinowskian sense (Malinowski I926), which is verified and reified to Hiko through the names of sites on and around the island of Ha'ano. This example of Tongan ecography thus physically emplaces the line of the Tu'iha'angana into $\mathrm{Ha}^{\text {'ano, }}$, by virtue of Hina's desire for Nganatatafu, and the product of their desire, the annual 'atu. In the next sections, I demonstrate just how deeply this narrative fulfills its role as mythic charter and as ecography.

The story begins with Ngana 'Eiki, son of a Tu'i Tonga, (or, in some versions, a Tu'i Tonga himself), stopping into $\mathrm{Ha}^{\text {' }}$ ano to pick up his younger brother for the voyage to Sāmoa. Why, is unclear, but is possibly explained by the Tongan proverb "'Oku 'ikai ha vaka 'e mate 'i tahi, ka 'e mole ai ha Ha'ano" (There is not a boat lost at sea, but someone of Ha'ano perishes). The people of $\mathrm{Ha}^{\text {'ano }}$ were, the proverb indicates, a sailing people. So perhaps Ngana 'Eiki wanted Nganatatafu's sailing skills for the voyage to Sāmoa; he certainly did not seem to want his company!

When telling the story, Hiko (or anyone else who knows it) points toward a particular spot on the fringing reef to the west of the village and identifies Ma'ukuomate, the spot where the Fijian attendant died. Beyond that

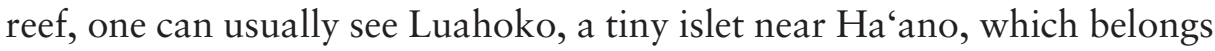
to the family of Vili Maea, one of the elder fishers of Ha'ano who has himself participated in a Tà'‘atu. No one lives on Luahoko (yet), although Vili Maea helped his uncle plant trees on it a couple of decades ago, and still uses it as a place to go for picnics, to fish, and to forage annually for bird's eggs. Someday, his family intends, the islet's ecosystem will be sufficiently transformed to be habitable. Until then it is an important landmark for Ha'ano sailors and fishers, and a resource in reserve. Luahoko helps one to sight the larger, but more distant island of Mo'unga'one, which is so far away, it is only visible from $\mathrm{Ha}^{\text {'ano }}$ if the tide is low and the sea is calm. The sea near Mo'unga'one is where Ngana 'Eiki told the young men 
to jump overboard. From the Ha'ano shore where one sees Luahoko and Mo'unga'one, one can also view the Ma'ukuomate reef, where the faithful Fijian attendant died. The 'api (land plots) near the shore, and overlooking the direction of Ma'ukuomate, Luahoko, and Mo'unga'one, are called Tu'ulautala ("stand and tell everyone") and Fotu'atama (a literal translation of Fotu'atama is "sudden/stunning appearance of the prince"). The 'api names are mnemonics, surely, for Nganatatafu's sudden appearance on the reef, red hair streaming with water, a dead Fijian in his arms, surrounded by a churning school of fish.

On the voyage back from Sāmoa, it is perhaps no coincidence that Ngana 'Eiki chose the ocean near Mo'unga'one as the particular spot to prepare kava, and the place to throw Nganatatafu and his Fijian attendant out of the boat. Mo'unga'one is known for its relationship to sharks: the people of Mo'unga'one claim a kinship with the sharks there. Tongans past (and present) view the shark as a moral arbiter, as do many other Polynesians. My interpretation is that Ngana 'Eiki intended Nganatatafu to be killed-Hiko is clear on that point-but if he did not drown first, then perhaps the sharks of Mo'unga'one would provide the appropriate punishment for his younger brother's transgression. (When I asked this of Hiko, he did not disagree, nor correct this as a misinterpretation, only saying, "Yes; there are a lot of sharks there!") As a dutiful younger brother, Nganatatafu undertook the trial imposed by his elder; as a chief with mana, he survived.

But what was Nganatatafu's transgression? There were two, actually. While genealogies that refer that far back in time are always contestable (and the events of this story would seem to date from some time between I 400 and I700 AD) Nganatatafu and Ngana 'Eiki were sons of the same parents. ${ }^{11}$ Tongan ideology is that the duty of the younger sibling is to support the elder sibling. But brothers of the same father are also potential rivals for the same titles, differentiated usually by their mothers' blood rank. With such factors being equal, age is the only differentiation. Theirs is therefore a difficult relationship, and the theme of a junior brother outmaneuvering his senior is repeated throughout Tongan (indeed Polynesian) historiography. In succumbing to his love for Hina (or simply seducing her, or allowing her to seduce him), Nganatatafu denied Ngana 'Eiki access to the ritually significant and politically advantageous union with the Samoan taupou (ceremonial virgin) of Aleipata. ${ }^{12}$ And so Nganatatafu's first crime was to disobey his brother's command to stay away from Hina, and thus usurp his elder brother's place in the hierarchy of privilege. 
Second, he took Hina's virginity, a highly valued form of sacred capital. The sacredness of such events and what they symbolized, including the "god-like prowess implied by the ritual defloration of aristocratic girls" was publicly vaunted, marked in smears of hymenal blood on the faces of the bride and bridegroom and on her 'ie sina (what Hiko called her ngafingafi) (Schoeffel I999, I 27). The generative potency of that chiefly virginal blood, and its symbolic ties to chiefly masculinity and aristocratic mana (Tcherkézoff $2004,40,102-103$ ) is still alluded to today, in the streaks of red coloring Tongan, Samoan, and many other Polynesian dancers place on their cheeks before they perform traditional dances.

As a normal part of the "conjunction of the noble blood lines" (Schoeffel I999, I42) enacted in such chiefly or high-ranking sexual alliances, the families exchanged large quantities of cloth wealth. Finely woven pandanus mats, some almost as fine as silk, are highly esteemed valuables that represent maternal principles of reproductive generativity (Weiner I992; Young Leslie 2006). In both Sāmoa and Tonga, they encode history through the events at which they are exchanged and the persons with whom they are associated. Thus chiefly deflowerings were, for a time, a source not only of building ritual mana but also of material wealth in the form of the Samoan textiles that flowed into Tonga from the exchanges centered around spousal alliances (Kaeppler 1978). At the same time, cloth wealth was (and is) used to ritually sacralize persons, events, and items (Young Leslie 2007). That she brought her ngafingafi/'ie sina demonstrates that Hina herself recognized and wished to preserve the sacredness of their copulation. Her reasons for keeping the cloth, rather than giving it to the man who deflowered her are not insignificant, as I discuss below.

Even as Nganatatafu's crimes, responsibilities, and audacities are demonstrated in the story of the Ta' 'atu, so are the expectations and failings of an aristocratic daughter. The character of Hina in this story is a double figure: a real Samoan woman named Salamasina who lived in Aleipata, and the pan-Polynesian goddess Hina. The real Salamasina is recorded in the genealogy of the noble Malupo, as the mother of sons who went on to originate two chiefly titles. Salamasina's first son was born while she lived with Ngana 'Eikimeimu'a as his wife, on the island of 'Uiha (also in Ha'apai); her second son was born while she was the wife of Nganatatafu on Ha'ano. Salamasina's first child was named Malupo'ofalefisi. He became the tupuanga or originator of the line of Malupo, the chiefs of the island of 'Uiha. Her second child was named Tu'iha'angana'otangata. He became the tupuanga of the line of Tu'iha'angana, the chiefs of Ha'ano. However, 
the narrative of the Ta'atu, in conjunction with a certain Tongan proverb, places the specific paternity of both sons in doubt: While born in 'Uiha, it seems likely that Malupo'ofalefisi was fathered by Salamasina's first love, Nganatatafu. Salamasina left 'Uiha and joined Nganatatafu, but she was already pregnant. Thus the younger brother, Tu'iha'angana'otangata, while born in Ha'ano, was fathered by Ngana 'Eiki. Deciding which child was of greater rank or higher parentage in this situation is complex: as her first child and elder brother of the pair, Malupo'ofalefisi would be higher in rank. Yet Tu'iha'angana'otangata was (presumably) fathered by Ngana 'Eiki, an elder brother and a Tu'i Tonga-recipient of a title descended from the god Tangaloa. Reflecting this complicated genealogy, the islands of 'Uiha and Ha'ano, as metonyms for their two titleholders, are referred to as the 'Ongo $\mathrm{Ha}^{\prime}$ 'angana-the $\mathrm{Ha}^{\prime}$ 'angana Pair.

Who was this Salamasina, and what was she like? Reading into the narrative as told to me by Hiko, and taking a feminist reading of the genealogy, I see a real woman who engineered the seduction process and chose the younger, more desirable Nganatatafu over his elder, higher-ranked, and more politically important brother, but who ended up married to and having children with both brothers in the type of serial monogamy that was typical of chiefly unions. Besides being beautiful, she seems to have been a particularly audacious woman: Salamasina's desires would certainly have gone against the expectations and plans of her 'ainga/kāinga (Samoan/Tongan: extended family). High-ranking Samoan daughters, as many have described (Keesing 1937; Schoeffel I999; Tcherkézoff 2004), were significant political valuables, embodiments of powerful, mystical, and sacred essences. Pampered and yet strictly managed, they were permitted little say over that sacred capital. As Serge Tcherkézoff noted (2004, $40)$, ceremonial deflowerings were performed manually and publicly, and in some cases, reluctant young girls were forcibly held by an elder. Their hymenal blood was ritually potent. To a great extent, the emphasis on public display of virginity persists today in Tonga: A traditional Tongan wedding includes a ceremony in which the hymenal blood, captured on a bedsheet, is publicly presented to the bride's paternal aunt (the mehikitanga), along with a roasted pig. If there is no blood, the pig is not brought. While it rarely happens, Vili Maea told me that if one presumed to fake the hymenal blood (ie, falsify premarital virginity), the man who had actually deflowered that bride has the right to publicly claim the loin from the roast pig (pers comm, I992). While Tongans are very modernized today, some of these expectations persist, as the recent scandal over a royal great- 
granddaughter's too early birth indicated (Pacific Islands News Association 2003). Tongan poet Konai Helu Thaman described these expectations in her poem, "You, the Choice of My Parents," as reflected in this extract (I999, I33):

You come clad in your fine mats and tapa cloth your brown skin bursting with fresh perfumed oil your eyes shining like stars in a clear nightyou, the choice of my parents

...

but you do not know me my prince save that I am first born and have known no other man I fit your plans and schemes for the future but you cannot see the real me my face is masked with pretence and obedience and my smiles tell you that I care I have no other choice

Whether in Samoan or Tongan terms, if the story of the Ta'a atu has any veracity, the actions of the real Salamasina, as a taupou of Aleipata, must have been deeply shameful to her family, and very risky for both Salamasina and Nganatatafu. Gifford described the punishment exacted in Tonga for such illicit seductions (I929, I 84): a public beating over the face and body with a portion of the coconut stem, complete with small coconuts (loholoho'i). Both man and woman would be beaten (and disfigured, perhaps killed). The punishment was mitigated if a marriage occurred. Salamasina's desire not to award Nganatatafu her ngafingafi may have stemmed as much as anything else from a desire to disguise their actions, avoid punishment, and preserve the option of passing on her ngafingafi at another time. ${ }^{13}$ The genealogy of Malupo and Tu'iha'angana records what does not appear in the narrative of the Ta'a'atu: that Salamasina went on to form a marital alliance with Ngana 'Eikimeimu'a. The complicated genealogy is marked by the name for the two titles-'Ongo Ha'angana-but it is also remembered in the adage, "Viku 'a e malo 'o 'Uiha" (The loincloth of 'Uiha is drenched). This saying uses the imagery of the embarrassment of a wet malo (traditionally made of barkcloth, which would fall apart if soaked) as a metaphor for the shame of being usurped or cuckolded: The Malupo line claims descent from Salamasina's first son and Ngana 'Eiki, 
but is (probably) descended from the younger and thus lower-ranked brother, Nganatatafu. On the surface, "Viku 'a e malo 'o 'Uiha" may therefore index Ngana 'Eiki's embarrassment, and by extension reference his anger and license as elder brother to command the younger Nganatatafu to jump out of the boat far from any shore and risk the judgment of the sharks. But as I see it, it also indexes the cleverness of Salamasina, and epitomizes the way in which Tongan hierarchy is both perpetuated and mitigated. Clever audiences can see in Salamasina a woman who indulged her desires, "pleased herself" (a well-known Tongan saying is "Fa'iteliha pe" [Please yourself]), and as a good mother, ensured that both her sons' parentage was, at least officially, of the highest rank, and that both became tupuanga of respected titles.

\section{Beauty, Bounty, And Bonito}

The character of Hina in the story of the Tà'atu is a complex heroine, one who defies the constraints placed on her by the (male) voice of the storyteller. The historical Salamasina, taupou of Aleipata and mother of the tupuanga of both the 'Ongo Ha'angana, is also Hina, a figure significant across Polynesia. Whether she appears as Hina (Hawai'i, Tonga), Hine (Aotearoa, Tahiti), Sina (Sāmoa), or Ina (Mangaia, Cook Islands), what is consistent across these narratives is that she is a very remarkable woman or goddess who is associated with fish, fertility, creativity, voyag-

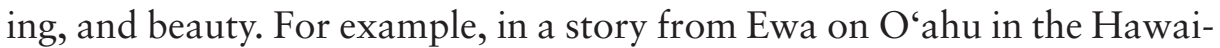
ian Islands, Hina'aimalama "turned the moon into food and the stars into fish" (Fornander I920, 266). In Fiji, Sina's fish patrolled and protected the village bay, at least until a Fijian chief made it into a gift of gratitude to the Samoan village of $\mathrm{Pu}^{\prime} a \mathrm{apu}^{\prime} \mathrm{a}$, where the fish (mullet) now resides (Enoka 2004). ${ }^{14}$ In Ra'iatea, Hina liked to fish and explore; she took her canoe all the way to the moon (Henry I928).

Fish as gifts, fish and generativity, fish and femininity-all are codeterminant in Polynesian experience. Beauty marks bounty; it is tangible evidence of mana. This is very clear in the story of the Ta'a atu. It may seem surprising therefore that we are not actually told much about what makes Hina so beautiful. The story is clear that her beauty is so renowned that Ngana 'Eiki is willing to voyage to Sāmoa to woo her, but the only available description of physical beauty refers to Nganatatafu and his radiant hair. We must read between the lines to discern Hina's beauty. Perhaps 
her status as sacred virgin, her genealogy, the high-ranking generations that she created, and the wealth she precipitated for Tongans-perhaps all these are the essence of her "beauty."

Normally, a male chief (Tongan or Samoan) would take with him the prestigious textiles that marked the young woman's ritual deflowering, along with large amounts of other valuables (koloa), acquired as part of the ceremonial exchanges marking a high-status marriage. These gifts were (and are) in fact analogues for the maternal kāinga/'ainga, capable of structurally replacing or replicating the maternal kin in ceremony. The fa'e huki, members of the maternal kin who literally hold a bride (and groom) in their laps in order to demonstrate that mothers "push up" their children (Young Leslie 2004), are structurally reiterated by the mound of textile koloa on which a bride and groom (or an infant at a first birthday ceremony) may be seated. Textiles are metonymic of the maternal kāinga / 'ainga and-because textiles are produced by women- of female investment and wealth potential (Young Leslie I999, 286-289; 2007). The 'ie sina, ngafingafi, or 'ie toga gifted at a deflowering and wedding thus represent both the genealogical nurturing and care invested in the offspring of a kāinga/'ainga, but also the potential fecundity and wealth generation of any young taupou or other ceremonial bride, through many future generations. After a deflowering, these textiles were both real valuables - tangible, exchangeable sources of wealth - and heirlooms of historic and mana-gathering events and persons. They were icons of that mana. Such prestigious textiles were usually named (fakaui), and could take on a life of their own, perpetuating over several generations the importance and status of their various holders.

In the Tà'atu story, Hina provides another type of generativity, another proof of her fecundity, another heirloom that transcends time and underwrites male authority with feminine fertility in the same way that Annette Weiner says cloth wealth does (I992): Hina provides the 'atu. In giving Nganatatafu her fish, Hina set up a cycle in which the chief of Ha'ano is personally and perpetually responsible - through his audacity, his beauty, his courage, and his lovability-for the bounty of the bonito that gives itself to Ha'ano.

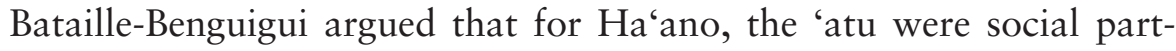
ners, guests from Sāmoa, who are treated as chiefs and respected as tokens of Hina's love for Nganatatafu (1988). But as I see it, the 'atu could be more than social partners; they could be family, a key part of a generative cycle whereby culture is inscribed on the landscape (and seascape), 
and the ecosystem is embodied in the loto (inner self) of the people. The cycle begins and ends with the return of the 'atu. One possible, structuralist interpretation of the narrative is that the 'atu are also doubled: both bonito, and a narrative representation of the offspring of Hina and Nganatatafu-in other words, that what Nganatatafu brought back from Aleipata was a child (or in some versions of the story, two children). This is not Hiko's interpretation. He tells the story literally, as if the 'atu are just bonito. Yet nonhuman offspring occur frequently in Tongan (and indeed all Polynesian) myths, and the sacred power of sexuality is thereby codified in the procreative acts that create the ecosystem. This pattern is perhaps more clearly represented in the Kumulipo of Hawai' $i$, which names pairs of generative principles that originate the world and all that populates it, beginning with Kumulipo and Po'ele (Lili'uokalani I 897; Beckwith I98I), and in Māori narratives of the origins of the world and the procreative powers of Wākea and Papatuanuku, sky god/father and earth goddess/mother, whose children were part-animal, part-vegetable, parthuman, and even stellar (Whatahoro I9I3). Despite Hiko's skepticism, I think it is notable that the restrictions on the Tu'iha'angana during the arrival of the bonito-stay in the house, with windows closed up, and sit, accompanied by one or two attendants-are similar to traditional ritual provisions made during labor and delivery of a child. In such times, too, it is normal for a mother giving birth to be closed up in the house. Here, I speculate: Was the Tu'iha'angana put in ritual seclusion because he was giving symbolic birth to his children, the 'atu? Is that the subtext for why striking the 'atu is forbidden? Or is the seclusion needed because Hina is bringing forth her children, who require protection from the strong tapu that, historically, meant that fathers were very sacred, and therefore physically dangerous, to their children?

If either of these interpretations were adopted, the 'atu would change from mere fish and social partners to family: kāinga/'ainga to the people of Ha'ano and Aleipata. In this interpretation, it is Nganatatafu and his heirs, the various Tu'iha'angana, who periodically, perhaps even annually, offered the elites of the realm a very high ranking form of sustenance indeed: members of their own kāinga. This is not unprecedented in Tongan mythic history. There are other examples of sacred (human) sacrifices offered to high-ranking chiefs, the most notable being the origin of kava itself, which sprang from the body of Kava'onau. She was cooked by her parents as their only suitable offering for a visiting Tu'i Tonga (see Biersack I99I; James I99I). 
As the myth provides a charter for sibling and offspring relations, so it provides templates for aristocratic behavior, including examples where such behavior is capricious, cruel, and self-serving. What is also true is that chiefs (male and female) are judged, desired, sought, and remembered for their beauty (however defined) as much as for their arrogance and adventurous exploits. Nganatatafu's swim and his delivery of the 'atu to Ha'ano were marvelous feats, worthy of historical memory, and obvious candidates for ecographic iconography. Hina's beauty and her love for Nganatatafu were so profound that she bypassed the eldest son of the Tu'i Tonga and provided the island where Nganatatafu lived with the bounty of the bonito. Why emphasize his beauty in the narrative? In part, it must be as a rationale for why Hina selected him as her first lover, rather than the more obvious choice of her parents, the higher-ranking and thus more powerful Ngana 'Eiki. But in Polynesian mythic poetry, beauty-the beauty of the man and the woman-is cause for renown, celebration, and historicizing. Chiefs, this story tells us, must be beautiful. Beauty, bounty, and bonito (in this case), are all linked, says the Tà'atu.

Careful genealogical trackers may note a disconnect between the biological heredity implied in the genealogy—in which Ngana 'Eiki's biological son becomes the originator of the Tu'iha'angana title, and Nganatatafu's biological son fathers the Malupo line-and the delivery of the 'atu to the chief of Ha'ano. This is indeed difficult to explain if one sticks to a Western conception of conception. Tonga kinship, however, treats all male brothers as "father" and all female sisters as "mother." While both boys might actually have been fathered by Nganatatafu, in terms of genealogical tracking, both Ngana "Eiki and Nganatatafu were "father" to Malupo'ofalefisi and Tu'iha'angana'otangata. It is also important to note, however, that in Tongan ontology, the title itself is a character that repeats through time, in the same way that Hina does; when a person adopts the "garland" of a title, even if they are genealogically collateral to (ie, not in a direct line of descent from) those ancestors, they become/inherit all prior privileges and histories of that title. Marshall Sahlins referred to this as the "heroic I" (I98 5, 47; see also Rumsey 2000); as such, the cast of prior holders is encompassed within the new owner of the name or title. At the same time, titles are integral to places; a title without a tofi'a (estate) and the people who live on it, is meaningless. Finally, in (pre-Christian) Polynesian epistemology, personhood is not limited to biological genealogy but is instead built or accreted and acquired through place and action (Linnekin and Poyer I990; Lieber I990). Thus 'atu go to the place of the 


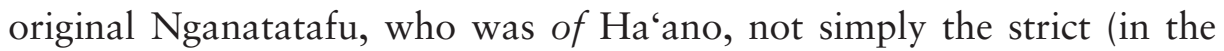
Western sense) biological descendant. Ideally, but not necessarily, place and descent are coterminous. That they are sometimes not, is hinted at in the adage, "Viku 'a e malo 'o 'Uiha." Yet, as Hiko says, that is not the end of the story!

\section{ECOGRAPHY AND RE-EMPLACEMENT}

The narrative of Nganatatafu and Hina may be construed as justifying the political status quo (as myth is often seen to do). In crediting Nganatatafu with the origin of the 'atu, the story of the love affair and Ngana 'Eiki's loss in the competition for Hina's deflowering is fundamental to the ancient Tu'iha'angana line's authority and claim to the loyalty of the villagers of $\mathrm{Ha}^{\prime}$ 'ano island. But while the ha'a Ngana (corporate kindred of the Ngana) are an old line in the Tongan chiefly hierarchy (Bott with Tavi I 982,95$)$, the history of human occupation on Ha'ano is far older than the genealogy of the ha'a Ngana. In I99I, when I first went to Ha'ano, there were still vague hints about a chief or deity who preceded the one called the Tu'iha'angana. This personage was called 'Otuangu.

I first heard about 'Otuangu while collecting a genealogy from an elderly Ha'ano woman, Folingi Katoa, in 1992. Folingi described her 'api tukuhau (widow's land allotment) as pertaining to the old chief 'Otuangu. All she could tell me about 'Otuangu was that she was a female, an 'eiki (chief), perhaps a Tu'iha'angana herself, and that "she had lived in Ha'ano before Havea" (Havea is the familiar name for the Tu'iha'angana). My interest was piqued, because female chiefs are rare in Tongan historiography, and because the name 'Otuangu itself is quite unusual. It does not appear in any local, or other, stories, nor does 'Otuangu appear in the lists of Tu'iha'angana titleholders. The most obvious of a few possible translations of the name is "Yam God/dess" (runner-up "is Grunting God/dess"). Since talking with Folingi and attempting to track this very unusual name, I have come across it three times. Once was in the Ha'angana genealogy, as a granddaughter of the tenth Tu'iha'angana and a woman named Monutapu'osi. Another was in reference to an elderly woman of mostly European and some Tongan ancestry who lived in the capital, Nuku'alofa, and told me (in I999) that she had been given the name in her youth by Queen Sālote; she knew nothing about its history, nor had she any connection to Ha'ano. The third occasion is current: the present-day Tu'iha'angana and his wife Mele Fakafanua told me in July 
2003 that they had been advised by Princess Nanasipau'u to include the name 'Otuangu in their daughter's string of chiefly names. They also told me they knew little of the origin or meaning of the name.

The evidence is tantalizingly fragmentary, but permits supposition: In pre-Christian Tonga, a common pattern for dealing with the problem of rival brothers was to disperse collateral and potentially competitive junior relatives to outer islands, where they could operate within their own domain of power, while at the same time providing potential allies in times of need; they also served as conduits for redistributions of wealth and provender in the seasonally cyclic ceremonies held in honor of the Tu'i Tonga's deity, the goddess Hikule'o. If 'Otuangu was, as Folingi told me, a pre-ha'a Ngana chief (something others have confirmed), or even a goddess who predated the rise of Hikule'o, it would come as no surprise that as one line of chiefs gained power over another, they used story as a strategy to situate themselves on the local landscape. For indeed, that is the key element of the Tà'atu story: it situates the Tu'iha'angana as the bringer of magical and prestigious bounty from Sāmoa, and therefore as legitimate chief of that place. The Tu'iha'angana's line has captured the 'atu in story and has used it to substantiate their authority and role in Ha'ano for several centuries. Without the 'atu, the various Tu'iha'angana are just autocrats. With the 'atu, the Tu'iha'angana becomes a true Polynesian chief, symbolic parent, and procreator replete with mana, a provider of a miraculous form of food-fish who jump on to the beach, begging to be caught.

The irony today is that the 'atu no longer come to the bay at Ha'ano in such great numbers that they leap on to the shore. Hina's bounty has gone astray. For whatever reason, the covenant extant among the Tu'iha'angana, contemporary representative of the beautiful and Olympian swimmer Nganatatafu; Hina of Sāmoa, lover and source of enduring wealth; and the people of Ha'ano, reapers of the 'atu, seems to have lapsed. The bounty that a chief brings by the very nature of his being-what in other places and times was called his mana-has for a long time been lacking. In an unfortunate parallel, as Hina's fish seem to have lost their connection to

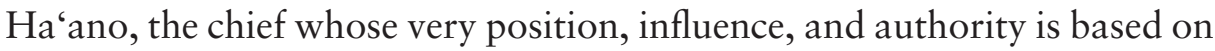
those fish does not, according to them, really know the people of his own estate very well. He has not (yet?) served as a conduit between the sacred realms or overseas sources of wealth and his people, and he is not very intimate with the ecography of his own estate. In part this is not his fault: the previous Tu'iha'angana died while the current one was very young, 
and the title was held in abeyance, awaiting his maturity. During that time (almost two decades), his mother raised him on Tongatapu, where the other high-ranking elites (including collateral relatives of the former Tu'iha'angana) were living and, in particular, schooling their children. The current Tu'iha'angana is a modern man, educated in and for a modern world, a young and respected politician working at national levels. He is also a young man who grew up apart from the terrain, the place, the land, sea, and inhabitants constituting the ecography that authenticates his title.

That the Ha'angana title was important in the past was recognized by Queen Sālote (Bott with Tavi I982, 95), but it had fallen in power and prestige even during her reign (which ended in 1965); it remains relatively insignificant in the politics of the kingdom. Now in his mid-thirties, the current Tu'iha'angana is making the right kind of political alliances necessary to re-elevate his title's status and provide for his estate. He has married the daughter of the current queen's sister and the powerful noble Fakafanua, he has recently been named Speaker in Parliament, and he is involved in parliamentary committees devoted to development in $\mathrm{Ha}^{\text {'apai. }}$ $\mathrm{He}$ is regarded as "promising" by many, but he seems more comfortable in the relatively urbane environment of the capital, and has only ever been to his rural and decidedly outer-island estate some four or five times in his life. This is something that privately embarrasses or saddens many of his kāinga (kin group/people of their traditional estate) living in the villages of his estate- the same places that historically cooperated when Hiko sent out the call, "Fish!"

Rather than the actual Tu'iha'angana, it has been Saia Fifita, the old man who has worn the tehina title of Hiko for decades, who has maintained the traditional chiefly presence in the village. For the story of the Ta'a'atu is about Hiko, too, as he well knows: "Find your younger brother so that he may manage the entire thing," said Hina, and Hiko is loyal to that instruction. And yet, as this Hiko ages and becomes frail, his "elder brother" Havea Tu'iha'angana seems not to recognize the symbolic significance of the role of the Hiko to Ha'ano and to his own chiefly authority. In this he is, again, not alone-many of the younger nobles were raised in the capital or overseas, where education and other opportunities were perceived to be better. Many nōpele (nobles/the new title for chiefs) and mātāpule (chiefly attendants) today actually get instruction from the Tongan Traditions Committee on how to fulfill their traditional mandate, because they have not experienced their estates or their ceremo- 
nial responsibilities in the same ways as their predecessors (Vou Vaea, pers comm, 2002). Likewise, when this Hiko passes away, the tehina title will be lodged with a man who has spent most of his adult life in the capital. And so, as the nobles ensconce themselves and their entourages in the urban center, and communicate with their kāinga via telephone and the occasional ceremony, the ecography of the village-recorded in names that tie together land, sea, creatures, adventures, and families, and that re-emplaces those spaces into their residents-fades from lived experience. Small wonder that in his retellings of the narrative of the Ta' 'atu in 2003 and 2004, the ninety-year-old Hiko should romanticize the past glories and emphasize his own role in the harvesting. Indeed, he may be the only person left alive who is connected both genealogically and experientially to the events of the narrative and the power of the ceremony. Without the man who has actually acted as intermediary between Hina and her lover the Tu'iha'angana, the man who waded into the ocean to offer kava to the fishes in the hopes of returning $\mathrm{Ha}$ 'ano to prosperity (and then severed the tie), without an ecographer such as Hiko in Ha'ano, the Tu'iha'angana's claim to the traditional love and devotion of the people of his estate, the people of Pukotala, Ha'ano, and Muitoa, is too distant, secular, and onesided. This is a scenario that ultimately mitigates against support for the hierarchical institution for which Tonga is famous, "the last Polynesian Monarchy."

\section{Geopolitics of Desire}

The narrative of the Ta'a atu is politically important. In the past, the story situated the place and people of Ha'ano within a set of important geographic and political frames. From the story we know that the kau Ha'ano were widely traveled and had connections to significant locations of the classical pre-Christian era: Ngana 'Eiki traveled from $\mathrm{Mu}^{\text {'a }}$ on Tongatapu (Tonga), seat of power of the Tu'i Tonga, to Ha'ano (Ha'apai, Tonga); to Aleipata on Upolu (Sāmoa); from there to Mo'unga'one (Ha'apai, Tonga); and back to Tongatapu. Hina sent her fish from Pulotu (deep sea/ancestral homeland/heaven) to Ha'ano. Nganatatafu's loyal attendant and swimming companion came from Fiji. The Tu'iha'angana and Malupo titles are recorded as predating many other titles and as descending from sons of a very early Tu'i Tonga, himself a descendant of the sky god Tangaloa. This is a narrative in which geography and genealogies are foregrounded. At 
the same time, it is a narrative that pivots on elements common in Polynesian myth and story, yet not generally reflected on in relation to voyaging: beauty and desire. Ngana 'Eiki hears of Hina's beauty and sails to Sāmoa to satisfy his desire for her. The young handmaidens see Nganatatafu on the shore and wonder if anything so beautiful can be human. The fame of his beauty has preceded him and helps them to recognize Nganatatafu, and leads Hina to break social conventions and risk family disapproval, perhaps even death. Hina's beauty leads Nganatatafu to gainsay his elder brother's wishes. Geography, we learn, is transected by desire, and beauty has political ramifications.

Indeed, much of the oral history and narrative of Polynesia emphasizes beauty and links it, rhetorically, to chiefliness, prowess, luck, and travel. The Tongan case, however, offers a somewhat different scenario from Sahlins's description of Polynesian chiefs as sharks who voyage across the sea, walk on the land, and become incorporated into new places by bedding local daughters (I98I, I I2; see also Dening I982). Nor are the ha'a Ngana the only ones to claim descent from a high-ranking woman from overseas. Sometime after pulling up the islands with his magic hook, Maui sailed to Pulotu to bring chiefly wives back to Tonga (see Filihia 200I); many other narratives told across Western and Eastern Polynesia, such as those represented by the Hina/Tinirau/Maui complex, show that it is women and men who voyage and emplace new generations. Thus, while it is tempting to think of an underlying theme of Tongan political expansion as being perpetrated by "seamen spreading semen" and "heroines planting humans" (as Sahlins's metaphor would imply), I think this is simplistic: Salamasina/Hina's proactive role, her control of her sexual activity, and her self-possession (not to mention her command over fishes and clever strategy to elevate both sons) demonstrate that it is equally valid to think of such stories as demonstrating themes of "women wooing warriors."

Regardless of how we label it, the story of Hina and Nganatatafu's mutual desire is one that places one currently insignificant island into a wider geopolitical ecology that antecedes contemporary Tonga. That the island of Ha'ano played a significant role at some part in Tonga's long voyaging history is attested to not only by its archaeological sites and the genealogies but also by proverbial references. At the same time, we cannot help but be reminded that in $2006, \mathrm{Ha}^{\prime}$ ano people do not sail anywhere, anymore; they no longer know how to navigate to Sāmoa, nor do they inspire much loyalty from Fiji. Today, other desires are operating in the 
seascapes and landscapes described in the narrative of the Tà'atu. Currently, the objects of desire are not high-ranking women from across the sea, but the analogue for Hina herself: her 'atu.

And so I return to the fish. I think it no coincidence that it was in the late I970s and early I980s that the people of Ha'ano began to worry about their annual runs of 'atu: commercial fishing increased dramatically in scope and efficiency throughout the Pacific during that period. The US fleet's landings of skipjack alone increased from 8,000 mt (metric tonnes) in 1979 , to a high of $124,300 \mathrm{mt}$ in 1984 . The take in I 990 was 107,400 mt (Coan I99I, table I). Fishing fleets using highly efficient purse seines, drift nets, or both, plus sonar and other techniques targeted the various kinds of tuna-the "chicken of the sea"-and in addition to freely fishing in international waters, they also poached between and within territorial waters of other nations (Doulman I987; Coan I99I; Bonnano and Constance I 996). Commercial rhetoric of the era described the ocean as a place of great economic resources and limitless bounty, with enough fish to feed the entire world. Fish and other ocean denizens who moved between the various nation-states, and the geostationary locales that represented their borders ${ }^{15}$ were only "protected" if they fell within the political boundaries of nations having the infrastructure to police their waters. Small island nations like Tonga (and many other Pacific nations) were essentially impotent when it came to preventing fish piracy or limiting the catch of fish not yet arrived in their waters (see Pacific Magazine 2006).

Today, in retrospect, we know that the bounty of the oceans is not limitless, and is susceptible to the effects of unbridled commercial enterprise. Overfishing and habitat destruction have had severe and deleterious effects on the denizens of the sea. At the same time, changes in global temperatures are affecting the Pacific Ocean in ways scientists are only beginning to understand. Ocean temperatures affect the spawning and migration patterns of pelagic fish (and mammals). The synergistic effects of El Niño or La Niña, overfishing, habitat destruction, and changes in ratios of fish species within the same ecological niche are not well understood. What is clear is that peoples and cultures historically dependent on and rich because of pelagic or anadromous fish-fish that return regularly to their people, fishes described by cultures around the world as sentient creatures giving themselves as gifts of love-are now having to face the repercussions of the near extinction of their fish/partners/kin. Like the cod that used to gather on the east coast of Canada, the varieties of salmon that traditionally supplied Scotland, the eastern and western coasts of Canada, 
the northern United States, and other nations, varieties of Pacific tuna are also at risk or considered to be overfished.

Recently, Tonga and other nations have sought to negotiate contracts with foreign fishers, to at least garner some cash returns from the harvesting that takes place in their waters. Unfortunately, from the perspective of the inshore fishers like those of Ha'ano, this looks less like cooperation, and more like coercion. As one fisher said to me in reference to Tonga's various trade and development deals with Chinese businesses and government: "The Chinese already have Tonga" (Sione T, pers comm, 2003). Xenophobia aside, the comments flag concerns by small-scale and subsistence fishers that they are being disregarded in national fisheries deals. While there have been moves to ensure that Tongan businesses participate in an open-ocean commercial fishery, this approach has not been as successful as was hoped, and is seen as something that benefits the urban population, rather than the rural, outer-island, subsistence fishers.

In general, the Tongan government's focus has been on national economic returns, modernization of the infrastructure, expansion of overseas markets, and adherence to international trade (ie, the World Trade Organization), population health (ie, the World Health Organization), and other neoliberal and transnational agendas. Little attention is paid to the ways in which the commercialization of the deepwater fishery will affect subsistence or local symbolic orders, including the cultural or traditional forms of authority. The relationship between a dependable fishery, and the loyalties of the people of a place to the chief for whom the place is the justification for a title, does not figure in discussions of national fisheries development. Yet, in a traditionalist community, these connections and disconnections are felt, even if not expressly articulated. Consider Ha'ano in I975, when the villagers realized that the runs of 'atu were no longer dependable, and Hiko performed the ritual to entice the 'atu's return. While in other parts of the Pacific, syncretism of Christianity and paganism is evident, this is not generally considered acceptable in Tonga. Concern must have been significant for people of a conservatively Christian village, that Hiko, a man raised as a Christian in a firmly Christian country, was willing to perform a ritual of supplication to a school of fish thought to come to the village by mystical, magical means connected to the kuonga po'uli-the dark ages of pre-Christian Tonga.

By 2004, the 'atu of Ha'ano, the resource perhaps partly responsible for 2,900 years of uninterrupted human occupation, the featured players in a tale of love and desire, seem to have succumbed to a different form of 
desire, one more distant, less sensitive to local needs, and certainly unwilling to follow the admonitions of Hina and to heed the call of Hiko. Thus, as the Ta'a atu harvest ritual and explanatory narrative are endangered, so too is the sacred foundation of the relationship between the "eiki (chief) of Ha'ano and his kāinga (people). In an era when the fish have failed to give themselves up, when their chief does not really know them as family, people living on Ha'ano island describe the Tu'iha'angana as "nice," "polite," "well-behaved," and "kind, because he does not demand a lot of traditional wealth from the people." But this cautious sentiment is a far cry from the "beauty," the audacity, and the passion that seduced Hina or inspired the Fijian's loyalty, or the wildfire rumors that spread all the way from tiny Ha'ano to the Aleipata region of Upolu in Sāmoa. The Tu'iha'angana and many others of his generation are very different types of "chief," operating within a very different set of geopolitical desires. Likewise the ecographer Hiko, an elderly man who will eventually be laid to rest in a tomb named for Aleipata, is also of a fading breed: the tehina whose mythic storytelling vivifies the history of the chief and his people within the place of their origins.

\section{Conclusion}

The story of the Ta'atu and the lovers Hina and Nganatatafu is a compelling source for thinking, as are all good myths. The story elements combine ambition, love, lust, betrayal, courage, seafaring skill, gender roles, and the moral privileges and obligations of elder and junior ranked persons. It emplaces the $\mathrm{Tu}^{\text {' } i h a ' a n g a n a ~ t i t l e h o l d e r ~ a s ~ t h e ~ r i g h t f u l ~ c h i e f ~ o f ~}$ $\mathrm{Ha}$ 'ano, perhaps as the replacement for a prior, female chief called 'Otuangu. All in all, as Hiko tells it, the narrative of the Tà'atu demonstrates a mythic history in which beauty and desire stimulate voyages, transect geography, prefigure fecundity, establish political power, and enable cul-

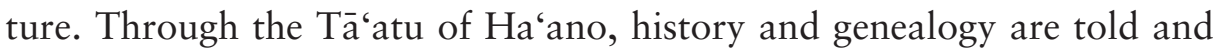
retold via the landscape and wider ecosystem, both of which are simultaneously inscribed and reinscribed in the lives of the people of the place. I refer to this process as "ecography." At the same time, in 2006, through the ecography of the lovers Hina and Nganatatafu, and of the Tà'atu, we cannot help but be reminded that Ha'ano's present is changing and the old forms of bounty are failing. State priorities aimed at ensuring neoliberal economic reforms for the national population have failed to consider how commercialization of the deepwater fishery will affect local symbolic 
orders, including traditional, culturally specific forms of authority. If this story reads too nostalgically, it is because Hiko, at a stage in his life when what he knows to be important is not respected, romanticizes what he knows and feels. At the same time, the narrative also depicts the nastiness open to high-ranking chiefs in the past, while highlighting the ideals for chiefly beneficence, ideals that exist as moral restraints on and expectations for elite power and privilege, even today.

In the last several years, the bonito have not run in such a way as to require a Tà'atu. In our modern times of commercial purse seining and drift-net fishing, of freezer ships harvesting vast amounts of marine stocks between and within the seas of island nations with no capacity to police their waters, the ecography of the Ta' 'atu is also an ecological cautionary tale linking the political fallout of the lust of beautiful youths in precontact Sāmoa and Tonga with contemporary politics of ecosystem overexploitation and dramatic shifts in traditional perceptions of the figure of the "chief." A fishy romance indeed: as it turns out, Nganatatafu of the Ta'a'atu story was a beautiful man because he was a bounty-providing chief for his people. Whether future chiefs will be the providers of similar bounties, or will in some way merit something like the enduring love of Hina (the goddess) and loyalty of others, such as the Fijian who followed Nganatatafu all the way to Ma'ukuomate, is an open question. The Samoan proverb "Tau ina uia le ala o le atu" (Let it go the way of the bonito) is said when the only gift someone has to offer is of lower quality than the recipient or occasion ideally requires. It is, in a roundabout way, a marker for the value of traditional ways. Chiefs like the current Tu'iha'angana are torn between a world of modern commercialism and a very old form of customary authenticity. How and whether they will be able to bridge this divide, for the good of their people, is yet unknown. And so, following Sappho's observation, we will have to see if these are men who will always beautiful be.

I am especially grateful to Saia Fifita, "Hiko-o-Ha'angana," whose memory is prodigious and whose storytelling and willingness to talk about Tongan culture has provided hours of pleasure and innumerable insights. I thank him humbly for permission to tell this story. To Sione Talia'uli, Loutoa Fifita and children, Vili Maea and Toa'ila Ngalu, as always, I am grateful for feeling part of the fämili. 'Ofa labi atu moutolu. Merci bien to Serge Dunis for enthusiasm, encouragement, and a new nickname, and to him, Sylvie Maurer, and Eric Waddell for inspired work on a translation of a prior version of this paper (Young Leslie 2005). Keith 
Chambers, Barbara Walker, and Will McClatchey told me of unpublished but relevant material. Leslie Butt, Shirley Lindenbaum, Ilana Gershon, Naomi McPherson, Jamon Halvaksz, Eric Waddell, Christine Jourdan, Peter Hempenstahl, Tèvita Ka'ili, David Gegeo, Lamont Lindstrom, Jukka Sikala, and Mark Calamia provided constructive feedback at various stages of the writing. I was able to finalize the paper while a visiting scholar at the Macmillan Brown Centre for Pacific Studies at the University of Canterbury, New Zealand, a wonderful opportunity for which I will always be grateful. Fakamālō atu 'eku si' $i$ kaunga'api mo toko'ua 'ofa'anga, ko Maile Drake, mo 'eku tuonga'ane 'i he vahaope ko Tèvita Ka'ili: Labi 'e ho'omou 'ofa kiate au! I am indebted to Maile Drake for Tongan language transcriptions, assistance with interpretation, and to her and Tèvita Ka'ili for ongoing practice in spoken Tongan. Finally, fakafeta' $i$ to the two reviewers for The Contemporary Pacific who were particularly helpful and encouraging. All errors are, of course, my own: kātaki fakamolemole ki mu'a.

\section{Notes}

I The Tà'atu story is known to varying degrees by many adult residents of the village, but is connected directly to the duties of the "Hiko" name holder. Elements of the Ta'a atu narrative have been recorded by earlier ethnographers (Gifford I924), and the term "Ta'‘'atu" appears in the most comprehensive of the Tongan language dictionaries, where it is defined as "the technique for catching bonito as unique to the village of $\mathrm{Ha}$ 'ano" (Churchward I959, 473). For these reasons, and because many Ha'ano people have migrated or married out, the story may be familiar to Tongans living in other parts of the kingdom as well. However, because it is not one of the stories usually taught in the primary school curriculum, nor has it been popularized in recent Tongan-oriented publications (see, eg, Fanua 1975, I982; Afuha'amango 1997), it exists as but one of the many vaguely familiar mythopoetic stories associated with pre-Christian Tonga.

2 Michael D Lieber first alerted me to the value of a hook without a barb (pers comm, I998; see also Lieber 1994). Essentially, when in the midst of a school of bonito or skipjack, a skilled fisher can snag a fish and swing it into the boat, snapping it off the hook on the fly, allowing for faster return of the hook to the water, with an increased likelihood of catching another fish from the swiftly swimming school. This is very important when chasing the school as a small crew paddles the canoe. Craig Severance and Robert Franco reference a similar process (without referring explicitly to the barb on the hook) in their description of traditional Samoan bonito fishing (I989).

3 While today a Polynesian atoll may be seen as emblematic of a self-sustaining paradise, the historic reality is more severe. Horticulture, like fishing, is highly 
dependent on the buildup of soil nutrients as well as weather patterns: drought and storms can ruin soils and crops. For early inhabitants, until root and other land crops were well established, there were long years of opportunistic marineterrain foraging. Archaeological records dating from the first two centuries of Lapita settlement in Tonga demonstrate extirpation of some fourteen species, and local extermination of many more: birds, fruit bats, sea turtles, shellfish, reef fish, and large-bodied iguanas (Burley I998, 355-356). This pattern was repeated across the Pacific (Kirch 2000).

4 In Ha'ano village there is a double tomb complex called Langi Lahi and Langi Si' $i$. (Langi is the royal term for burial place, lahi means large, si'i means small). This is the traditional burying place of the Ha'angana elites, including, as

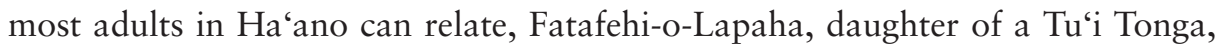
wife of Fifitapuku, the fifteenth Tu'iha'angana (see also Burley I992, I00-I04; I994). Also, unlike most other parts of Tonga, on Ha'ano even non-elite people bury their dead in crypts lined and capped with ancient, dressed-rock slabs. Such structures required large amounts of human power as well as dependable and abundant reef and sea resources.

5 I am grateful to Lamont Lindstrom and one anonymous reviewer for pointing out that the injunction against selling the fish indicates that the story itself has been modified at some point in its telling (not unusual, as mythic narratives are made relevant for the time in which they are told). The anachronism may indicate, in part, discomfort with mercantilization of a sacred resource, at some point in the story's past. Nevertheless, the Tongan society and economy that Saia Fifita grew up in was long affected by mercantile behaviors, introduced by eighteenthcentury whalers, traders, and missionaries. For a Hiko born during World War I, an injunction against selling the fish from a Tà'atu is not anachronistic.

6 Ika Katoa, a fisheries officer who was born in Ha'ano, says that when bonito sense blood in the water, the school will dive to the bottom and stay there (pers comm, I992). If true, this behavior would effectively allow the fish to escape the net/curtain used to block their leaving the bay at Ha'ano; knowledge of that behavior seems implied in Hina's instructions. At the same time, Lautala Taufa's recollection of the Ta' atu in which he participated included the fact that he ended up covered in a lot of fish blood (pers comm, 2004).

7 Fish piracy is indeed an ongoing problem in the Pacific; vessels belonging to Chinese companies, among those of many other nationalities, have been caught fishing in waters to which they have no rights. Tongans' reference to the Chinese here reflects other political concerns in Tonga as well as the fact that Tonga had recently signed a deal to permit Chinese vessels to fish within Tonga's exclusive economic zone limits, and that the Chinese fishing industry has grown extremely rapidly: "from 1980 to 1995 , the total Chinese fish catch increased from 5 million to 25 million metric tons $(\mathrm{mt})$ per annum, ranking China first in terms of global annual output of aquatic products and accounting for more than $20 \%$ of world 
fishery production" (Woodrow Wilson International Center for Scholars 1997). However, despite Tongan inshore fishers' depictions of Chinese as fish pirates, the worst offenders in the Pacific overall have been the Americans, whose fishing fleets were the first to introduce large-scale, distant-water purse seining in the Pacific; they used reductions in foreign aid to punish nations who seized illegally fishing US ships, and resisted fishing compensation payments until Kiribati sold fishing rights to the Soviet Union. Finally in 1987 the United States signed a multilateral treaty (New Internationalist 2000). Concerns over lost revenue due to fish piracy and damage to fish ecosystems has resulted in measures such as the Multilateral Fisheries Partnership Agreement, drafted in November 2006, and aerial patrols by the Royal Australian Air Force of waters in Fiji, Tonga, Sāmoa, Tuvalu, Vanuatu, and Solomon Islands. The patrols are specifically oriented against illegal fishing (Pacific Magazine 2006).

8 The tape-recorded version was transcribed with the assistance of Maile Drake, who also acted as consultant on the translation. The extent of the adaptation is limited to providing context (in square brackets] or ensuring narrative flow.

9 For a detailed discussion of Tongan pandanus textiles, see Young Leslie 2007.

Io There are other parallels with ritual fishing methods, such as in the Trobriands (Malinowski I9I 8), and Kapingamarangi; Kenneth P Emory recorded a Kapinga bonito chant that could be describing Hiko and the Tà'atu (I965, 332, parentheses in original):

Motomaumau reports that the water off Hetau is being ruffled

(He) calls upon his late father, "Bring my school to enter the pocket at Kuatirongo"

Reaching the two coral heads by the open reef (in the south), the water swirls over the reef.

The man at the pocket of the net at Rakau islet exclaims,

"A fish strikes between the eyes the priest-of-the-north-end-(of-Touhou)"

(The ariki of the starboard canoe). He was speechless (with fright).

I I The genealogy of Ngana 'Eikimeimu'a and Nganatatafu lists their father as the twentieth Tu'i Tonga Tatafu 'Eikimeimu'a. A predecessor of Tatafu 'Eikimeimu'a was Talakaifaki, the fifteenth Tu'i Tonga. Talakaifaki figures in both Tongan and Samoan narratives as the Tu'i Tonga who was expelled from Sāmoa, and as the inspiration for the highly ranked Samoan title "Malietoa." His life is dated to roughly the early thirteenth century. Measuring genealogies is fraught with pitfalls, but it seems safe to say that the events recorded in the Tà'atu would have taken place between the late thirteenth and the sixteenth centuries.

I2 Aleipata is in the southeastern corner of the island of Upolu, in Sāmoa. 
Upolu figures significantly in Tongan historiography, insofar as the current dynasty is that of the Tu'i Kanokupolu (Flesh of Upolu).

I3 The first time Hiko told me the story, Hina suggests that Ngana 'Eiki might confiscate the koloa. The point made earlier regarding the anachronistic injunction about selling the 'atu also applies to Hina's supposed concerns with sale of the ngafingafi. The point that I think the storyteller(s) try to make is that the bonito are even more eternal than textiles.

I4 The themes and practices associated with a traditional fish harvest in Sāmoa are remarkably similar to the Tà'atu: according to Enoka (2004):

Samoan legend has it that chief Lemalu of Pu'apu'a was gifted the I'a Eva [traveling fish, a mullet with red lips] in return for his generosity in hosting an old lady named Sau, originally from Tufutafoe....

So at certain times of the year, Lemalu and the people of Pu'apu'a will go out and catch shoals of fish using nets. This practice involves a lookout for the fish on the reef. Once sighted, Ta'ala [the lookout] will signal by waving his canoe paddle to alert Lemalu. As the aitu o le I'a (god of the fish), Lemalu will go out to the reef and guide the fish into the bay, which is lined with nets in preparation for their arrival. The fish enter the bay and once they notice the nets, will start to jump, just as it was told in the legend. . . .

Before going out to fish, Lemalu and the fishermen must conduct an "ava" ceremony at dusk.

No one is allowed to visit or leave Lemalu's maota (the chief's house) during the fishing season.

The fish must be caught only as they leap into the air with hand nets.

I 5 The "exclusive economic zone" borders are imposed on what are essentially fluid locations, as if they were not fluid. The borders are arbitrary, non-visible, and essentially tacked to the globe in much the same way that geostationary satellites are.

\section{References}

Acheson, James M

I98 I Anthropology of Fishing. Annual Review of Anthropology Io:2753 I6.

Afuha'amango, Tuituiohu

I997 Princess Hina and the Eel. Auckland: Princess Hina Books.

Baker, Beatrice Shirley

I9I6 Nganatatafu moe e 'Atu 'a Hina. Ko e Fanogonogo [Tongan Wesleyan newsletter, Nuku'alofa] I (7): 7-8. 
Bataille-Benguigui, Marie-Claire

I988 The Fish of Tonga: Prey or Social Partners. Journal of the Polynesian Society 97 (2): I85-I98.

Beckwith, Martha, translator and editor

I972 The Kumulipo: A Hawaiian Creation Chant. Honolulu: University Press of Hawaii.

Biersack, Aletta

I99I Kava'onau and the Tongan Chiefs. Journal of the Polynesian Society I00 (3): 23 I-268.

Bonnano, Alessandro, and Douglas H Constance

I996 Caught in the Net: The Global Tuna Industry, Environmentalism, and the State. Lawrence: University Press of Kansas.

Bott, Elizabeth Spillius, with Tavi

I982 Tongan Society at the Time of Captain Cook's Visits: Discussions with Her Majesty Queen Sālote Tupou. Polynesian Society Memoir 44. Wellington, NZ: The Polynesian Society.

Brody, Hugh

I98 I Maps and Dreams: Indians and the British Columbia Frontier. Vancouver: Douglas \& MacIntyre.

Buck, Peter (Te Rangi Hiroa)

I950 Material Culture of Kapingamarangi. Bernice P Bishop Museum Bulletin 200. Honolulu: The Bishop Museum.

Burley, David V

I992 Archaeological Research in the Ha'apai Islands, Kingdom of Tonga: Activities of the I99I Filed Season. Manuscript on file, Department of Archaeology, Simon Fraser University.

I994 The Temple of Faleme'e: Archaeological and Anthropological Considerations of a Pre-Christian God-House on the Island of Ha'ano, Kingdom of Tonga. New Zealand Journal of Archaeology I 6:55-67.

I998 Tongan Archaeology and the Tongan Past, $2850-150$ B.P. Journal of World Prehistory I 2 (3): 337-392.

Burley, David V, and William R Dickinson

$200 \mathrm{I}$ Origin and Significance of a Founding Settlement in Polynesia. Proceedings of the National Academy of Sciences 98 (20): I I 829-I I 83 I.

Butler, Virginia L

I994 Fish Feeding Behaviour and Fish Capture: The Case for Variation in Lapita Fishing Strategies. Archaeology in Oceania 29:8 I-90.

200I Changing Fish Use on Mangaia, Southern Cook Islands: Resource Depression and the Prey-Choice Model. International Journal of Osteoarchaeology I I:88-100.

Churchward, C Maxwell

I959 Tongan Dictionary. Nuku'alofa: Government of Tonga. 
Coan, Atilio L, Jr

I99 I USA Distant-water and Artisanal Fisheries for Yellowfin Tuna in the Central and Western Pacific. In Interactions of Pacific Tuna Fisheries, volume 2: Papers on Biology and Fisheries, edited by Richard S Shomura, Jacek Majkowski, and Sarah Langi. Proceedings of the First FAO Expert Consultation on Interactions of Pacific Tuna Fisheries, 3-I I December 199 I Nouméa, New Caledonia. United Nations Food and Agricultural Organization Fisheries Technical Paper 336/2.

Dening, Greg

I982 Sharks that Walk on the Land: The Death of Captain Cook. Meanjin 4I:427-437.

Dickinson, William R, David V Burley, and Richard Shutler, Jr

I994 Impact of Hydro-Isostatic Holocene Sea-Level Change on the Geologic Context of Island Archaeological Sites, Northern Ha'apai Group, Kingdom of Tonga. Geoarchaeology: An International Journal 9 (2): 85-III.

Doulman, David J

I987 Development and Expansion of the Tuna Purse Seine Fishery. In Tuna Issues and Perspectives in the Pacific Islands Region, edited by David J Doulman, I33-I60. Honolulu: Pacific Islands Development Program, East-West Center.

Emory, Kenneth P

I965 Kapingamarangi: Social and Religious Life of a Polynesian Atoll. Bernice P Bishop Museum Bulletin 228. Honolulu: The Bishop Museum.

Enoka, Angelynne

2004 The Legend of I'a Eva. Events Polynesia Web site. http://www .eventpolynesia.com/events/samoa/archive/SA3_page_iaeva.htm [accessed I6 April 2006]

Evans, Mike

200I Persistence of the Gift: Tongan Tradition in Transnational Context. Waterloo, ON: Wilfred Laurier University Press.

Fanua, Tupou Posesi

I975 Po Fananga: Folk Tales of Tonga. San Diego: Tofua Press.

I982 Po Tatala. Nuku'alofa: Tonga Extension Centre and University of the South Pacific, Tonga.

Feit, Harvey

I99I The Construction of Algonquian Hunting Territories: Private Property as Moral Lesson, Policy Advocacy and Ethnographic Error. In Colonial Situations, edited by George W Stocking, Jr, I09-I34. Madison: Wisconsin University Press.

I995 Hunting and the Quest for Power: The James Bay Cree and Whitemen in the Twentieth Century. In Native Peoples: The Canadian Experience, 
edited by R Bruce Morrison and C Roderick Wilson, IOI-I 28. Second edition. Toronto: Oxford Press.

Filihia, Meredith

200I Men Are from Maama, Women Are from Pulotu. Journal of the Polynesia Society I Io (4): 377-390.

Finney, Ben

I993 Voyaging and Isolation in Rapa Nui Prehistory. Rapa Nui Journal 7 (I): I-6.

Fornander, Abraham

I920 Collection of Hawaiian Antiquities and Folklore. Volume 5. Honolulu: The Bishop Museum.

Gifford, Edward Winslow

I924 Tongan Myths and Tales. Bernice P Bishop Museum Bulletin 8. Honolulu: The Bishop Museum. Reprinted by Krauss Reprint Co. New York, I97I.

I929 Tongan Society. Bernice P Bishop Museum Bulletin 6I. Honolulu: The Bishop Museum. Reprinted by Krauss Reprint Co. New York, I 985.

Gosden, Chris

I992 The Humid Tropics. World Archaeology 24 (I): 55-69.

Gunther, Erma

I928 A Further Analysis of the First Salmon Ceremony. University of Washington Publications in Anthropology 2 (5): I 29-I73.

Henry, Teuira

I928 Ancient Tahiti. Based on material recorded by J M Orsmond. Bernice P Bishop Museum Bulletin 48. Honolulu: The Bishop Museum.

Irwin, Geoffrey

I992 The Prehistoric Exploration and Colonization of the Pacific. Cambridge, UK: Cambridge University Press.

James, Kerry

I99I The Female Presence in Heavenly Places: Myth and Sovereignty in Tonga. Oceania 6I (4): 287-308.

Jenness, Diamond

I95 5 The Faith of a Coast Salish Indian. Edited by Wilson Duff. Anthropology in British Columbia Memoirs in Anthropology 3. Victoria: British Columbia Provincial Museum.

Kaeppler, Adrienne

I978 Exchange Patterns in Goods and Spouses: Fiji, Tonga and Samoa. Mankind I I:246-252.

Kamakau, Samuel

I993 Tales and Traditions of the People of Old. Translated from the newspapers Ka Nupepa Kuokoa and Ke Au Okoa by Mary Kawena Pukui; edited by Dorothy B Barrère. Honolulu: Bishop Museum Press. 
Kawaharada, Dennis

[2000] The Settlement of Polynesia, Part I. Polynesian Voyaging Society Web site, http://leahi.kcc.hawaii.edu/org/pvs/migrationspartı.html. Circa 2000. [accessed 24 February 2003]

Keesing, Felix M

I937 The Taupou System in Samoa: A Study of Internal Change. Oceania 8:I-I4.

Kirch, Patrick V

2000 On The Road of the Winds: An Archaeological History of the Pacific Islands before European Contact. Berkeley: University of California Press.

Kirch, Patrick V, and J Ellison

I994 Paleoenvironmental Evidence for Human Colonization of Remote Oceanic Islands. Antiquity 68:3 I0-32I.

Kirch, Patrick V, and Roger Green

200I Hawaiki, Ancestral Polynesia: An Essay in Historical Anthropology. Cambridge, uk: Cambridge University Press.

Leach B F, M Intoh, and I W G Smith

I984 Fishing, Turtle Hunting, and Mammal Exploitation at Fa'ahia, Huahine, French Polynesia. Journal de la Société des Océanistes 79:183I97.

Lieber, Michael D

I990 Lamarkian Definitions of Identity on Kapingamarangi and Pohnpei. In Cultural Identity and Ethnicity in the Pacific, edited by Jocelyn Linnekin and Lin Poyer, 7I-ror. Honolulu: University of Hawai'i Press.

1994 More Than a Living: Fishing and the Social Order on a Polynesian Atoll. Boulder: Westview Press.

Lili'uokalani

I 897 Prayer of Dedication. The Creation for Ka I i Mamao from him to his daughter Alapai Wahine, Lili'uokalani's Great-Grandmother. Composed by Keaulumoku in 1700 and translated by Lili'uokalani during her imprisonment in I 895 at Iolani Palace and afterwards at Washington Place Honolulu. Boston: Lee and Shephard. http://www.sacredtexts .com/pac/lku/lkuoo.htm [accessed 7 March 2007]

Linnekin, Jocelyn, and Lin Poyer

I990 Introduction. In Cultural Identity and Ethnicity in the Pacific, edited by Jocelyn Linnekin and Lin Poyer, I-I 6. Honolulu: University of Hawai' $i$ Press.

Malinowski, Bronislaw

I91 8 Fishing in the Trobriand Islands. Man I 8:87-92.

I926 Myth In Primitive Psychology. London: Kegan Paul. 
Marshall Thomas, Elizabeth

2003 The Lion/Bushmen Relationship in Nyae Nyae in the I950s: A Relationship Crafted in the Old Way. Anthropologica 45 (I): 73-78.

The New Internationalist

2000 The Great Tunafish Sandwich Hunt. The New Internationalist 325. http://www.newint.org/issue325/contents.htm [accessed 2I September 2005]

Pacific Islands News Association

2003 Tonga Royal Family Mum on Reported Birth. I 8 November. Online at Pacific Islands Report: http://archives.pireport.org/archive/2003/ november/I I-I 8-05.htm. [accessed 7 March 2007]

Pacific Magazine

2006 Australia: Surveillance Assistance Provided To Island Nations. Pacific Magazine, 24 August.

Perminow, Arne Aleksej

200 I Captain Cook and the Roots of Precedence in Tonga: "Leading" and "Following" as Naturalised Concepts. History and Anthropology I 2 (3): $255-288$.

Rumsey, Alan

2000 Agency, Personhood and the "I" of Discourse in the Pacific and Beyond. Journal of the Royal Anthropological Institute 6 (I): IOI-I I 5.

Sahlins, Marshall

I98I Historical Metaphors and Mythical Realities: Structure in the Early History of the Sandwich Island Kingdom. Association for Social Anthropology in Oceania Special Publication I. Ann Arbor: University of Michigan Press.

I 985 Islands of History. Chicago: University of Chicago Press.

Schoeffel, Penelope

I999 Samoan Exchange and "Fine Mats": An Historical Reconsideration. In Kie Hingoa "Named Mats," 'Ie Toga "Fine Mats" and Other Treasured Textiles of Samoa and Tonga. Special issue of the Journal of the Polynesian Society IO8 (2): I I7-I48.

Severance, Craig, and Robert Franco

I989 Final Report: Justification and Design of Limited Entry Alternatives for the Offshore Fisheries of American Samoa, and an Examination of Preferential Fishing Rights for Native People of American Samoa Within a Limited Entry Format. Report submitted to Ms Kitty Simons, Western Pacific Regional Fishery Management Council, I I64 Bishop Street, Suite I405, Honolulu, Hawai'i.

Stevens, Charles

2002 Constructions of Time, Ideas of Nature: Tongan Poetry and the Anticipation of Seasons. Paper presented at the American Anthropological Association meetings, New Orleans, 20-24 November. 
Tcherkézoff, Serge

2004 First Contacts in Polynesia: The Samoan Case. Canberra: Pacific and Asian History, Research School of Pacific and Asian Studies, The Australia National University.

Thaman, Konai Helu

I999 You, the Choice of My Parents. In Songs of Love: New and Selected Poems (1974-I999), I33-I34. Suva: Mana Publications.

Weiner, Annette

1992 Inalienable Possessions: The Paradox of Keeping-While-Giving. Berkeley: California University Press.

Whatahoro, $\mathrm{H} \mathrm{T}$

I9I3 The Lore of the Whare Wananga, or, Teachings of the Maori College on Religion, Cosmogony and History. Translated by S Percy Smith. Memoirs of the Polynesian Society 3-4. New Plymouth, NZ: Printed for the Society by Thomas Avery.

Woodrow Wilson International Center for Scholars

I997 Chinese Fisheries and International Cooperation on Oceanic Issues. Online at Columbia Earthscape: http://www.earthscape.org/pı/ecsi 6/. October. [accessed 7 March 2007]

Young Leslie, Heather E

I999 Inventing Health: Tradition, Textiles and Maternal Obligation in the Kingdom of Tonga. PhD dissertation, York University, Canada.

2004 Pushing Children Up: Maternal Obligation, Modernity and Medicine in the Tongan Ethnoscape. In Globalization and Culture Change in the Pacific Islands, edited by Victoria Lockwood, 390-4I3. Upper Saddle River, NJ: Prentice-Hall.

2005 Bons Baisers De Samoa: Les Bonites De Hina et Le Tu'iha'angana de Tonga. Bulletin de la Société Études Océaniennes 303/304:92-I3I.

2007 ... Like a Mat Being Woven. In Hybridity and Pragmatic Creativity: Authentic Innovations in Pacific Cloth, edited by Ping-Ann Addo, Heather E Young Leslie, and Phyllis Herda. Special issue of Pacific Arts ns 3-5: II 5-I 27.

\section{Abstract}

What can fish stories tell us about how people live with the complexities of rapid environmental transformations and the local effects of national, globalized, and neoliberal desires for resources? To answer this, I take the Tā'atu fish harvesting ritual and accompanying oral narrative to be an "ecography" that addresses human intimacies and changes on a small atoll in Tonga. This type of analysis draws on traditional ecological, political, and sociological knowledge, as well as 
geography, history, and cultural symbols, to give a deeper understanding of place and the contemporary experience of people intimate with the local environment as source of food and livelihood. When examined in the light of today's drastically depleted stocks of Pacific pelagic fishes such as skipjack tuna, the ecography of the Ta' 'atu provides a benchmark for a shift in a human-fish relationship that provided Polynesians with practical and poetic sustenance for hundreds if not thousands of years. At the same time, the myth of the Ta'a atu highlights the historic political importance of desire, beauty, and their confluence with bounty, in the production of generations of chiefly privilege and cultural practice. Imbricated with the shifts in human-fish and beauty-bounty relations are lessons for the contemporary chiefly-commoner relationship in Tonga, the last nation to claim status as an uninterrupted Polynesian kingdom, as well as laments for the loss of independence an important food resource offered. Today, as in the past, the Táa atu is a fishy tale about the geopolitics of various desires.

KEYWORDS: beauty, chiefs, ecography, environment, fishing, narrative, Tonga 